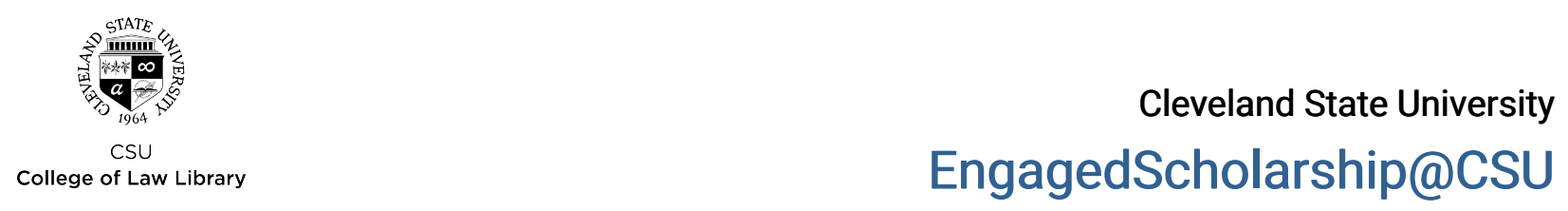

Law Faculty Articles and Essays

Faculty Scholarship

Summer 2010

\title{
Redesigning the American Law School
}

David R. Barnhizer

Cleveland State University, d.barnhizer@csuohio.edu

Follow this and additional works at: https://engagedscholarship.csuohio.edu/fac_articles

Part of the Legal Education Commons

How does access to this work benefit you? Let us know!

\section{Original Citation}

David R. Barnhizer, Redesigning the American Law School, 2010 Michigan State Law Review 249

(Summer 2010)

This Article is brought to you for free and open access by the Faculty Scholarship at EngagedScholarship@CSU. It has been accepted for inclusion in Law Faculty Articles and Essays by an authorized administrator of EngagedScholarship@CSU. For more information, please contact research.services@law.csuohio.edu. 


\section{HEINONLINE}

Citation: 2010 Mich. St. L. Rev. 2492010

Content downloaded/printed from

HeinOnline (http://heinonline.org)

Thu Oct 4 15:57:04 2012

-- Your use of this HeinOnline PDF indicates your acceptance of HeinOnline's Terms and Conditions of the license agreement available at http://heinonline.org/HOL/License

-- The search text of this PDF is generated from uncorrected OCR text. 


\title{
REDESIGNING THE AMERICAN LAW SCHOOL
}

\author{
David Barnhizer
}

\author{
2010 MICH. ST. L. REV. 249
}

TABLE OF CONTENTS

I. SUMMARIZING THE COMPETITIVE TRENDS THAT WILL IMPACT

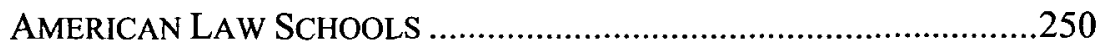

II. LAW SCHOOLS AS "MANUFACTURING" SYSTEMS OF PRODUCTION OF NEW LAWYERS..................................................260

III. ACTIVE AND RESIDENT LAWYER POPULATION BY SELECTED

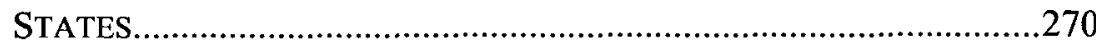

IV. LAW SCHOOLS' NEW LAWYER PRODUCTION .................................272

V. SOBERING MARKET INFORMATION RELATED TO THE LEGAL

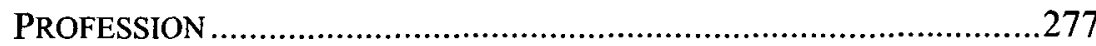

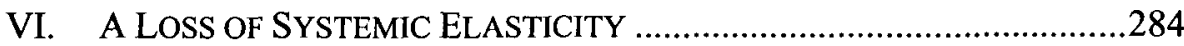

VII. RESTRUCTURING OF THE TRADITIONAL JOB MARKETS ....................287

VIII. THE PENDING SHIFT TO "OUTCOME" ASSESSMENTS IN ABA LAW SCHOOL ACCREDITATION STANDARDS AND THE POTENTIAL IMPACT ON LAW SCHOOLS.

IX. DEFINING THE ABA'S LEGITIMATE ROLE IN ACCREDITATION IN THE CONTEXT OF SCHOLARL Y PRODUCTIVITY ................................292

X. DESCRIPTION OF A POSSIBLE "UNIVERSITY OF PHOENIX" OR KAPLAN UNIVERSITY LAW SCHOOL SYSTEM ……….......................295

XI. ECONOMIES OF SCALE PRODUCED BY AN ALTERNATIVE MODEL ...301

XII. POSSIBLE COMPETITIVE SOLUTIONS DEPENDING ON THE NATURE OF THE SPECIFIC LAW SCHOOL .........................................302

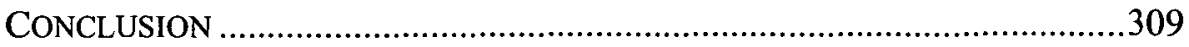

* Visiting Professor (recurring) University of Westminster School of Law, London; Senior Associate Research Fellow, Institute of Advanced Legal Studies, University of London; Professor of Law Emeritus, Cleveland State University. During the preparation of this draft I received helpful comments from a variety of people. This includes Daniel Barnhizer, Susan Becker, Joan Howarth, Joseph Harbaugh, Steven R. Smith, Geoffrey Mearns, Stephen Lazarus, Heidi Robertson, Rodney Jones and Roy Stuckey. I also thank numerous members of the University of Toledo law faculty to whose forum an initial draft of the Essay was presented. 


\section{SUMMARIZING THE COMPETITIVE TRENDS THAT WILL IMPACT AMERICAN LAW SCHOOLS}

In other industries, when there is a decline or severe curtailment of the demand for their product, we see companies downsizing, laying off personnel, bankruptcies and reorganizations, mergers to create greater economies of scale, and even dissolutions. American law schools have to this point been able to operate largely without any required adaptation to the economic realities of demand for their product. For many institutions that "free ride" is ending. It will become increasingly clear that law schools are part of a rigid and intractable business system in the same way that large firms and solo practitioners are driven by their need for financial resources required to sustain their conditions of operation and for some their survival. As those resources shrink, whether through reduced enrollments, declining state budgetary support or university cutbacks, many law schools will face economic challenges that generate significant impacts on how they operate.

The economic downturn being experienced in the United States in virtually every area of activity is not a simple cycle but a transformation. This non-linear shift in competitive conditions demands changes in behavior, institutional structures and assumptions in many areas, including education. Until recently, law schools occupied an insulated and parochial world exempt from real financial pressures. That is changing dramatically and the conditions that have begun to surface will only intensify.

A new system is being created that will be more complex and multifaceted than the traditional approach that has characterized American legal education. For a substantial number of U.S. law schools and law faculty who have taken the security and permanence of their employment for granted, their future is captured by the lyrics of Bruce Springsteen's "My Hometown"- "[T] The "brave new world" of legal education will be dramatically changed and part of that change will be that quite a few law faculty members will find

1. BRUCE SPRINGSTEEN, My Hometown, on Born IN THE U.S.A. (Columbia Records 1984). "For the first time in decades, the promise of a profitable law career for top students is uncertain, as law schools report significantly reduced hiring rates. . . Law schools across the country are seeing a reduction in the number of firms participating in the recruitment process. Harvard Law School reported a 20 percent reduction in the number of employers participating in recruitment, according to Assistant Dean for career services Mark Weber, while New York University, Georgetown and Northwestern reported on their Web sites that on-campus interviews are down by a third to a half when compared with recent years. The University of Texas at Austin experienced a 45 percent decrease in on-campus interviews ... ." Emily Watkins, Tough Market for Law School Grads: Law Students Across the Country Try to Adapt in a Struggling Economy, ABC NEws (November 26, 2009), http://abcnews.go.com/Business/tough-market-law-school-grads/story?id=9120629\&page=1 (last visited October 3, 2010). 
themselves with reduced incomes, restricted or non-existent tenure options, and higher teaching workloads. ${ }^{2}$ In many instances, tenure-track and even tenured law faculty in schools that are vulnerable to the emerging competitive alternatives will replicate the stunning experiences of millions of whitecollar workers in America's industries, who thought they had good-paying life-long jobs, only to find themselves on the streets as their companies downsized or went out of business. ${ }^{3}$

2. See, e.g., Scott Jaschik, Law School Tenure in Danger?, INSIDE HIGHER Educ. (July 26, 2010), http://www.insidehighered.com/layout/set/print/news/2010/07/26/law.

The American Bar Association is moving ahead with changes in its accreditation system that faculty members fear could erode tenure protections for many professors and further weaken job security for clinical faculty members, many of whom don't have tenure to start with.

A special committee of the ABA last week released the latest version of proposed guidelines on academic freedom-just days before an ABA committee met Saturday to discuss (but not alter) the draft language. In the weeks before the draft was released, many faculty leaders had urged the ABA panel not to do the two key things its draft does:

- Remove language from the ABA standards that has been interpreted by faculty members as requiring law schools to have a tenure system. (The ABA panel that wrote the revisions now says that tenure was never a requirement and that it is removing references to tenure for reasons of clarity -although that interpretation of current policy is being met with much skepticism.)

- Remove specific language requiring law schools with clinical professors and legal writing professors to offer them specific forms of job security short of tenure. The ABA panel recommending the changes has stressed that the accreditation requirements still insist that law schools protect academic freedom, and that many law schools would not necessarily change their tenure or other job protection procedures. The report accompanying the most recent draft characterizes the protections for clinical faculty members that would be eliminated as "intrusive mandates" that "are not the proper providence of an accreditation agency" and that eliminating them would "provide approved law schools with latitude and flexibility to articulate and implement policies to attract a qualified faculty and protect faculty academic freedom."

Id.

3. Mandated furloughs and layoffs are already occurring and are likely to increase and become more widespread. Nor, as reflected in the ABA's review of tenure standards in the context of accreditation as noted in footnote 2 above, is it inevitable that life tenure continue in many institutions in its present form. See, e.g., Paul L. Caron, Florida State Lays Off 21 Tenured Faculty, 15 Tenure-Track Faculty, TAxProf BLOG, (Feb. 19, 2010), http://www.typepad.com/services/trackback/6a00d8341c4eab53ef0120a8b5d7e5970b; Paul L. Caron, Presidents Join Deans in Asking ABA to Remove Faculty Tenure as Accreditation Standard, TAXPROF BLOG, (Jan, 27, 2010), http://www.typepad.com/services/trackback /6a00d834lc4eab53ef0120a81 l f20a970b. The university presidents and deans argue:

We urge the ABA Council to remove from its Standards for Approval of Law Schools all Standards and Interpretations that require that a law school must provide specified terms and conditions of employment to its faculty and others. In particular, we urge the Council to remove the Standards and related Interpretations listed on Schedule A attached to this Statement. 
The challenge is whether law schools will adapt to the changing environment through intelligent strategic choice or ignore the dynamics of change. If law schools elect to ignore the options that can improve their competitive positions they will endanger their ability to respond in ways that protect their institutional qualities and improve performance in a transforming educational and employment marketplace. Achieving positive strategic action is not a simple matter, however, because U.S. law schools are not structured or managed in ways that allow easy adaptation or downsizing.

Any member of a law faculty who has gone through efforts to make what are minor changes to law curricula understands how argument, turf protection and elevated rhetoric purportedly grounded on intellectual criteria are used to sabotage change. In such a situation, it seems delusional to contemplate a situation in which traditional law faculties will collectively decide on coherent and effective strategies that will inevitably alter their workplace conditions and focus. The power of professorial parochialism and the belief that "the sky is not falling" makes it virtually impossible to achieve intelligent strategic change in legal education from within the institutions themselves. It is outside forces and external institutions that will force the process.

To "feed their habit," American law schools require more than 40,000 new students each year to generate revenues sufficient to pay the bills for their operating expenses. That "habit" is the preservation of an archaic form of graduate level education whose structure, development, and monopoly as the means to gain entry into the lawyers' guild was a convenient accommodation to universities in need of money. Law schools attached to universities originally offered a cheap form of instruction from which universities were able to profit. ${ }^{4}$ This was a marriage with the organized legal profession whose members were happy to accept the prestige associated with the university degree. Universities, however, are now under significant finan-

Such requirements are unrelated to the quality of the education that our law schools provide and for which we are responsible. To our knowledge, no other accrediting agency authorized by the Department of Education requires specific terms and conditions of employment. While the accrediting standards of other agencies do vary in approach and content, none of them to our knowledge specifies the employment arrangements that the accredited educational program must have with its faculty and employees. Instead, they all focus solely on the resulting quality of the educational program, which is the purpose for accreditation in the first Id. place.

4. These issues are discussed at some length in David Barnhizer, The University Ideal and the American Law School, 42 RUTGERS L. REV. 109, 144-153 (1989) [hereinafter Barnhizer, The University Ideal]. 
cial stress. ${ }^{5}$ As the stress intensifies the financial cushion and "cash cow" status accorded many law schools will no longer exist. For some schools the result will be a budgetary Armageddon.

Many of the competitive forces that are emerging to confront a significant number of American law schools are seemingly independent and unrelated. But they are increasingly producing a package of negative dynamics, the components of which are coalescing in ways that will alter how at least half the schools conduct business, even to the point of survival for some. Not all schools will be affected negatively, and some will muddle through while others reap the benefits of competitors' decline.

But numerous law schools can be expected to experience dramatic pressures that they are unlikely to anticipate. Even if they are able to anticipate those pressures, they may be unable to create effective strategies that allow them to adjust their operations in time to avoid serious consequences. The final section of this analysis outlines some of the strategic options from which choices can be made that could help law schools deal with the challenges. Some of the options are simple and straight forward. Others will require a radical set of changes outside the political will of most academics.

Prior to considering available options, however, we need to better understand the competitive factors that are likely to have the most significant effects, and gain a sense of the nature of those impacts. I argue that they include the following considerations:

1. Radical changes in the "Law Job" markets are occurring at every level of private practice;

2. There is saturation of the market represented by fee-paying clients able or willing to carry the burden of legal fees while the number of lawyers seeking those clients has grown dramatically;

3. There is also saturation of the "absorptive capacity" of the solo practice niche into which several hundred thousand law graduates have flowed in the past decade due in part to the disappearance or shrinkage of other legal employment opportunities;

4. The legal profession is experiencing substantial movement toward company "In-House" law firms that will further undermine the concept of the individual law firm form of law practice as the "house"

5. See, e.g., Karin Fischer, America Falling: Longtime Dominance in Education Erodes, Chron. Higher Educ. October 5, 2009 available at http://chronicle.com /article/America-Falling-Longtime/48683/; Dennis Jones, State Shortfalls Projected to Continue Despite Economic Gains: Long-Term Prospects for Higher Education No Brighter, NAT'L CeNTER PUB. POL'y \& Higher EduC. (Feb. 2006), http://www.highereducation.org/ reports/pa_shortfalls/index.shtml. 
lawyers increasingly perform tasks previously "farmed out" to private firms;

5. High educational debt for law graduates $(\$ 80,000-\$ 150,000)^{6}$ inhibits employment choices and is increasingly unmanageable as real incomes fall for many solo and small firm practitioners;

6. Growing awareness among potential law school applicants of the high cost of legal education and the reduced probability of a corresponding return on that investment will alter the willingness of some applicants to assume that financial burden;

7. Some law schools are seeking to gain competitive advantages by creating, expanding or preserving a competitive advantage that attracts applicants and/or convinces potential employers of the soundness of their educational program and the merit of the school's graduates. Examples of such attempts include the University of Dayton law school's 2-year curriculum in which students are able to shorten the time spent in law school and enter the job market at an earlier point, ${ }^{7}$ dispute resolution and trial advocacy concentrations that offer apparent advantages in preparing students for law practice, and the significant focus on environmental concentrations at Vermont Law School ${ }^{8}$ and Lewis \& Clark;

8. Shrinking incomes for many lawyers versus increasing costs of education, the growing expenses of law practice, health care, etc. will contribute to changes in applicant interest and a more sophisticated selection of law schools by applicants intent on matters of cost and employment probabilities;

9. Increasing challenges to the legal profession's restrictive rules against the Unauthorized Practice of Law (UPL) from paralegals, as well as real estate, insurance, estate and wills professionals without law degrees but with extensive experience and competence in those fields will ultimately break the profession's monopoly over the provision of legal services. This will further exacerbate the financial

6. See Law School Educational Debt Has a Manageable Solution, ABA Now, http://www.abanow.org/2009/1 1/law-school-educational-debt-has-a-manageable-solution/ (last visited Jan. 17, 2011). "Every year, law students embark on a three-year course of study that will prepare them for a rewarding profession, but will also likely leave many of them with more than $\$ 80,000$ of debt. It is increasingly common for law graduates to owe $\$ 100,000$ or $\$ 150,000$ and even more." $I d$.

7. Earn Your J.D. in Two Years, University of DAYTON SCHOOL OF LAW, http://www.udayton.edu/law/academics/two_year_option.php (last visited Jan. 26, 2011).

8. Environmental Law Center, VERMONT LAw SCHOOL http://www.vermontlaw.edu /Academics/Environmental_Law_Center.html (last visited Jan. 26, 2011).

9. Environmental and Natural Resources Law Program, Lewis \& Clark LAW, http://law.lclark.edu/programs/environmental_and_natural_resources_law/ (last visited Jan. 26, 2011). 
problems of the legal profession and weaken the exclusive control over entry into law practice now enjoyed by law schools;

10. The changes in the competitive position of traditional law schools will be further undermined by the rise of "Function-Specific Educational Institutions" that can train people for discrete areas of legal representation in as little as six months to one year as alternatives to traditional law schools;

11. Expansion in the work disciplines (insurance, real estate, estates and trusts, domestic relations) concerning who is permitted to provide legal advice and representation will bring non-lawyers and businesses into the competitive fields historically controlled by lawyers;

12. There will be increasingly significant impacts produced by emergent technologies on the traditional model of university-based legal education in ways that make it possible to reduce the costs and number of faculty required to conduct a legal education;

13. Intensely pressured public and university budgets will increasingly produce demands to cut law school costs, while undermining tenure, increasing faculty workloads and depressing salaries;

14. The rise of corporate-owned, "University of Phoenix-type" law schools offering part-time and Internet based "distance learning" options will offer a significant alternative to traditional law schools requiring students to be in residence;

15. Distance Learning will be a key element of the competitive challenges and will occur both within some of the traditional law schools and in "On-Line" law schools such as Concord; and

16. Information management technologies linked with lower cost feedback mechanisms will become common within some schools, and these informational access and management technologies have already altered the nature of labor efficiency within the legal profession. The technologies have made it possible to access information, conduct research and writing and perform tasks such as filing electronically rather than physically delivering hard copies of pleadings to courts in ways that have simultaneously enhanced lawyer, paralegal and secretarial efficiency. This has also resulted in radically altering the employment needs of the legal profession due to the enhanced efficiencies because more can be done with less labor.

In addition to the competitive factors described above there are added considerations to keep in mind. These include the following:

- It Is a Transformation, Not a Cycle. The effects of the economic downturn on the legal profession have already been significant, and they are not merely transient shifts before the system moves back to 
its prior state, but a fundamental change in the way law practice is conducted.

- The End of Lawyers? There will be increasing pressures from nontraditional competitive sources without traditional law degrees to have a share in the business that has been limited to licensed lawyers. Richard Susskind, Professor Emeritus at Gresham University, analyzes this expansion of the right to practice some form of what is currently considered licensed law practice in his book titled, "The End of Lawyers."10 Susskind raises themes of what lawyers would call the unauthorized practice of law, in which others demand to be allowed to perform many of the actions traditionally thought of as being restricted to lawyers."

- Who Is Allowed to Practice Law? The lines between the provision of legal services as a distinct professional phenomenon, contrasted with being simply another bundle of services offered by a business are breaking down.

- Multi-Disciplinary Practice. There are, for example, trends in the United Kingdom such as more expansive multi-disciplinary practice authorization and a push to list law firms on the stock exchange as some law firms in Australia have already started doing.

- Mixing Law Practice and Other Business Forms. The trend toward allowing new forms of the "law business" appears to be more prevalent outside the U.S. Large-scale firms in the U.K. are shifting to more generic company status. They are becoming businesses with equity ownership held by interests other than solely or primarily by lawyers and with participation in the business by practitioners of traditionally non-law disciplines. In the U.S. one can imagine Walmart opening in-store law firms that are able to offer stunning price savings to clients in the relatively simple and technical areas that provide the "bread and butter" for much of private law practice. $^{12}$

10. See generally RICHARD SUSSKIND, THE END OF LAWYERS? RETHINKING THE NATURE OF LEGAL SERviCES (2008). A leading American scholar on legal ethics and professionalism based at the George Washington University School of Law, Thomas Morgan, has described the trends and conditions affecting the U.S. legal profession and challenged its right to continue any claim to that status according to the terms of what comprises professionalism itself. See ThOMAS D. MORGAN, THE VANISHING AMERICAN LAWYER 19-66 (2010).

11. See generally SUSSIKIND, supra note 10 .

12. In the UK this is referred to as "Era of "Tesco law" with Tesco being a major British supermarket chain. See Era of "Tesco law" Is Upon Us, Times ONLINE (November 15, 2006), http://business.timesonline.co.uk/tol/business/law/article1087184.ece. The Times report indicates:

The [Legal Services Bill] . . w will lead to the biggest shake-up in the UK legal profession in a generation, [and] will allow non-lawyers to own and operate law 
- Challenging the Bureaucracies that Control the Right to Provide Legal Services on a State-by-State Basis. One of the barriers to adaptive change in the U.S. is that there are many bureaucracies invested in this work that sustain the form of the current system. Several core issues in the U.S. include the dependence on state-bystate admission to law practice and constraints on what is referred to as the "unauthorized practice of law."13 The American model of single [state-by-state] jurisdiction licensing and practice is antiquated. Law as practiced today is often global, let alone state restricted. Some of these rules are likely to be overcome by a "domino effect" as the pressures grow to better match the reality of modern law practice with the terms under which it operates.

- Altering Unauthorized Practice of Law Rules. The "unauthorized practice of law" laws are a part of the problem. There is a big difference between unmet legal needs and legal demand. That is, in part, because legal services are unaffordable to many. That, in turn, is largely attributable to the high cost of a legal education, which needs to be recouped. This is attributable to that fact that you need a law degree to be licensed as an attorney, even though non-lawyers can be trained to do much of the work in a much shorter span of time and at lesser cost.

- Entry Barriers. There are numerous types of entry barriers, both legitimate and illegitimate. They involve matters of timing, imposed standards, legal rules concerning the unauthorized practice of law, state-by-state limits on the right to offer legal services, educational mandates that may be unrelated to the ability to offer quality

firms for the first time. Until now, firms of solicitors and barristers' chambers could only be owned by the lawyers themselves as partners.

The AA, the car breakdown and insurance group, and Halifax, the high street bank, have already begun offering limited legal services in anticipation of the changes. Both companies are outsourcing the work to external solicitors but will eventually be able to employ their own legal staff.

The Bill will also strip the legal profession's representative bodies of their ability to handle complaints against their members, setting up an independent Office for Legal Complaints.

Id.

13. The unauthorized practice of law rules tend to be vague once one moves beyond the outlines of the ABA's Model Rules of Professional Conduct Rule 5.5 that discusses the ethics of unauthorized practice by lawyers not licensed in a specific state or under suspension. A useful explanation of potential unauthorized practice considerations for paralegals can be found at: Unauthorized Practice of Law, NATIONAL Association OF PARAlEgal Associations, http://paralegals.org/displaycommon.cfm?an=1\&subarticlenbr $=333$ (last visited, Jan. 16, 2011). Of substantial interest is the fact that it is clear that some paralegals either function under extremely loose supervision by a licensed lawyer or even operate as independent actors. Id. 
legal service to clients, and financial costs associated with obtaining the required educational degrees and preparing for bar examinations.

- Entry Barriers. Entry barriers include the requirement that those aspiring to be lawyers in the U.S. must earn an undergraduate degree, complete a three-year graduate program in law school, pass a character assessment, pass the Multistate Professional Responsibility Examination, and pass a bar examination in the state where the aspiring lawyer desires to practice law. These erect quite significant, lengthy and expensive barriers before an individual is allowed to engage in any activity that could be considered the practice of law.

- Entry Barriers. In a competitive economy, such stringent barriers to entry to a particular form of economic activity should, one would assume, be allowed to stand only on a showing of direct connection and relevance to the ability to successfully perform the work that is otherwise prohibited. Monopolies are inherently suspect, and the "system" of becoming a lawyer and being allowed to practice is clearly a monopoly with the predictable, anti-competitive effects that monopolies produce. ${ }^{14}$

- Entry Barriers. In the 100 years in which law schools and the ABA have forged their monopoly over entry to the right to engage in the practice of law, there has been no data or serious studies that can be said to demonstrate the superiority of the ABA/law school system as necessary in order to produce people qualified to offer legal services.

- Entry Barriers. The unquestioned assumptions of the existing system about such matters as the best format, content and structure of legal education and the appropriateness of the ABA and selfinterested state bars and highest courts as the exclusive arbiters of entry into the profession and regulation of lawyers have helped to suppress the ability of others to offer alternatives for education and the provision of legal services. ${ }^{15}$

- Entry Barriers. One set of entry barriers to creating law schools has been the significant capital investment required to create and sustain a law school if it is to be accredited by the ABA. This may be on the way to a reduced factor. A hint of this shift might be detected in the ABA's announcement that it is going to start looking more

14. See, e.g., F. Zemans \& V. Rosenblum, The Making of a Public Profession 123 (1981) (making the point that formal legal education has a "virtual monopoly over preparation for entry into the legal profession").

15. For discussion of these issues see Barnhizer, supra, note 4; David Barnhizer, The Revolution in American Law Schools, 37 CLEVELAND ST. L. REv. 227 (1989). 
closely at "output" or "outcome" rather than capital "input" in its accreditation processes. ${ }^{16}$

- Entry Barriers. The ABA has also decided to review its standards concerning accreditation of distance learning as a method of providing legal education. ${ }^{17}$ This review will occur in 2010.

- Entry Barriers. There are limits to what an accrediting group such as the ABA ought to be allowed to impose, particularly when it also operates as a monopoly over access to the right to offer legal services to the public. The ABA dominates law schools and sets the standards of accreditation for the vast majority of public and private law schools. A rational legal test should include the requirement that any standard is both necessary and related to the quality of education in ways that are essential to the intellectual and practical development of effective lawyers.

- Entry Barriers. The legitimacy of the ABA, law schools, and state supreme courts being allowed an effective monopoly over entry to the legal profession should be looked at with suspicion. It should be continued only if a strong empirical case can be made for its necessity and quality.

- Entry Barriers. At the very least, the question of whether lowercost systems of legal education can be designed that achieve equivalent or perhaps even better outcomes in terms of educational quality for professional performance should be examined closely. In fact, the combination of the possible accreditation of distance learning for some legal education and the beginning development of a network of corporate-owned law schools for profit offering legal education at considerably less expensive rates will, within five years or so, hit many American law schools in ways that could devastate the traditional format and mechanisms of legal education.

- Is the Traditional Model the Best or Exclusive Model of Effective Legal Education? The problem for many middle-range law schools is that if legal education is assessed on the basis of the performance

16. See William D. Henderson, Henderson: Outcome Measures and Regulatory Failure in Legal Education, TAX Prof Blog (November 12, 2009), http://taxprof.typepad.com/taxprof_blog/2009/11/henderson-.html. Henderson is commenting on the Report of the Outcome Measures Committee. ABA Section of Legal Education and Admission to the Bar, AM. BAR Ass'N (July 27, 2008), http://www.abanet.org/ legaled/committees/subcomm/Outcome\%20Measures\%20Final\%20Report.pdf.

17. This process has been slowly evolving for nearly a decade. See, Martha Neil, Virtual Lawyers: Online Law School Produces Its First Graduating Class, ABA J. at 27 (December 2002); see also Bar Association May Ease Online Law School Restrictions, GETEDUCATED.COM http://www.geteducated.com/hot-careers/justice-law-legal-studies/273bar-association-may-ease-online-law-school-restrictions (last visited Jan. 17, 2011) [hereinafter GETEDUCATED.COM]. 
of its products or graduates, and if experimental models of education are proposed that end up generating graduates who are as effective on bar exams and their demonstration of knowledge and skills as those following traditional paths, then the schools and ABA will have a hard time sustaining their monopoly.

- Should We Restrict Enrollment? A possible strategy could involve capping the number of law students admitted each year, as does the medical profession to some extent through its accreditation process, through successful Congressional lobbying to limit the funds available for internships following graduation from medical school, and by being able to restrict the numbers of new medical schools until recently. ${ }^{18}$

- Should We Create More Rational Entry Barriers? Another approach could be toughening up the bar admission requirements (mandatory unpaid apprenticeships (à la medicine again) that "increase" the cost of entry and decrease supply of those willing to pay to become lawyers).

- Should the Accreditation and Curricular Power of the ABA and State Supreme Courts Be Reduced or Altered? Options for action include the possibility of altering or removing the current accreditation system and creating competition for legal education. They also include removing anti-competitive entry barriers for specific forms of legal services, reducing the costs of legal education and reducing the time required to obtain a law degree. Of obvious importance is the need to reduce the numbers of law schools and the volume of law graduates.

\section{LAW SCHOOLS AS "MANUFACTURING" SySTEMS OF PRODUCTION OF NEW LAWYERS}

American law schools are an integral-but in some ways a disconnected - part of a vertically integrated system of production in which the end product is lawyers. Rather than thinking of law schools only as academic institutions, we need to look at them as systems of production just as any other system of production of goods and services. This helps to demystify law schools as being independent and hermetically sealed systems with scant connection to the competitive conditions of the real world. Even

18. For an overview of how this restriction on access to the medical profession worked, see Lew Rockwell, The Trouble with Licensure, LEWROCKWELL.COM, republished from the Ludwig Mises Institute http://www.lewrockwell.com/archives/fm/08-90.html (last visited Jan. 17, 2011); see also Shikha Dalmia, The Evil-Mongering of the American Medical Association, REASON.COM (August 27, 2009), http://reason.com/archives/2009/08/27/theevil-mongering-of-the-amer. 
while many law faculty members remain impressively oblivious to the potential effects of external conditions on their institutions, factors generally considered external to legal education have much to do with the competitive conditions of law schools, including viability in some cases.

The issue with which this Essay is primarily concerned is the impact on the structure and viability of the current largely homogenous version of the American law school caused by an interconnected set of economicrelated trends affecting the supply of "law jobs," and the effect of pending ABA accreditation changes that shift the accreditation focus from "input" measurement to "output" or "outcome" measures determined mainly in reference to bar passage, employment after law school, and educational debt loads. That institutional form of legal education has experienced important changes since its emergence in the late nineteenth century, but in essence the structural model has remained in place for more than a century. ${ }^{19}$

This approach is useful because it reminds us that it is important for the production volume of any system offering goods and services-whether it be cars, televisions, computers or lawyers - to be in a proper relation with the demand for the product or service being produced. When viewed as a system of production, or supply of a product or service created for a consumer market, it is legitimate and strategically important to take into account the scale of the "consumer" demand for that product and the absorptive capacity and elasticity of the systems into which the products are being placed. ${ }^{20}$ For law schools, there are multiple sources of consumer demand. These include the initial applicant market for those aspiring to become lawyers, and the complex and multi-faceted demands by the numerous niches of potential purchasers of the "product," i.e., the many niches of activity that in some way provide legal services to clients. ${ }^{21}$

19. See generally Barnhizer, The University Ideal, supra note 4; David Barnhizer, The Revolution in American Law Schools, 37 CLEv. ST. L. Rev. 227 (1989).

20. The decline is dramatic on numerous fronts. See, e.g., NAT'L ASs'N FOR LAW Placement, PERSPECTIVES ON FAll 2009 LAW StUdent ReCruITING (2010), available at http://www.nalp.org/uploads/PerspectivesonFallRec09.pdf ("As the U.S. and global economies were battered by 'the Great Recession' in the third quarter of 2009 , recruiting volumes by U.S. legal employers on the campuses of U.S. law schools nose-dived. In fact, the data provided by NALP members about fall 2009 recruiting reveal that most of the trends and patterns that the industry had come to rely upon were upended, dramatically so in some cases. All of the markers that measure the strength of the legal employment market for new lawyers, such as law firm recruiting levels for summer programs and summer program outcomes, fell in 2009 , continuing and accelerating the general downward trend in recruiting volumes that was measured in 2008 . Related to the drop-off in the numbers in the second year of the recession was the phenomenon of deferred associate start dates."); Karen Sloan, Summer Associate Offers Hit 17-Year Low, Says NALP, NAT'L L.J., Mar. 3, 2010, available at $\mathrm{http}: / /$ www.law.com/jsp/nlj/PubArticleNLJ.jsp?id=1202445314748.

21. Paul L. Caron, 21\% of Law Students Regret Attending Law School, TAxPROF BLOG (Dec. 11, 2009), http://taxprof.typepad.com/taxprof_blog/2009/12/21-of-law- 
From a purely economic perspective that has nothing to do with curriculum or quality matters involved in American legal education, there is a critical disjunction between the number of law schools in the United States, the absolute number of graduates with which they are continuing to "load" the system, and the competitive conditions of the system represented by the volume of demand for legal services on the part of clients or organizations capable of paying for the provision of those services. This is entirely distinct from the issue of the unmet need for legal services in society.

It is easy to construct a model whereby it can be demonstrated that the theoretical need (if only someone were willing and able to pay) far outstrips the ability of lawyers to meet it. It is the economic demand, one determined by clients able and willing to pay for those services, that controls the competitive terms of practice in the private sector of the legal profession. Competition for clients and fees in this private sector of law practice is the problem or determining force, not the theoretical demand for legal representation across the board.

Of course there is a very large unmet need for legal services both in terms of access to services at an affordable level and in access to quality legal service. Even where there is some reasonable degree of pay for public defenders and appointed defense counsel in criminal cases there are significant deficiencies in the quality of what is provided and those problems are obvious and continuing. Therefore, on the surface, even though there is the appearance of providing legal services by means of appointed counsel or public defenders, the reality is that far too often it is an illusion when judged by the quality of service. ${ }^{22}$

students.html. "According to a new LexisNexis State of Legal Industry Survey of 550 respondents (300 private practice attorneys, 150 in-house corporate counsel, and 100 law students): $65 \%$ of law students (and $90 \%$ of lawyers) say that law school teaches legal theory, but does not teach the practical business skills needed to practice law in today's economy[;] 35\% of law students responded that they do not feel adequately prepared to succeed in the changing legal marketplace[;] $21 \%$ of law students say that based on the changing legal marketplace, they regret attending law school." Id; see also LEXISNexis, STATE OF THE LEGAL INDUSTRY SURVEY (2009), www.lexisnexis.com/.../State_of the_Legal _Industry_Survey_Findings.pdf (last visited Dec. 29, 2010).

22. Laura Bischoff points out the predictable dearth of quality as the consequence of Ohio's appointed counsel fees for serious felony cases. She asks:

If your loved one were charged with rape or murder, would you want him to rely on an attorney who would be paid no more than $\$ 500$ to defend him? What if he were facing the death penalty, and the lawyer's pay was capped at $\$ 6,000$ ? In Ohio, some counties have set the maximum fees for appointed counsel so low that attorneys are being asked to represent indigent defendants for as little as $\$ 150$ in juvenile court, $\$ 500$ for a felony in adult court and $\$ 225$ for a misdemeanor in adult court. In Knox County, the appointed counsel fees are capped at $\$ 6,000$ in a death penalty case. The capped fee has to cover expenses, such as expert witnesses and investigators, as well as attomey time. 
American law schools occupy a radically hierarchical structure in terms of status and prestige. Harvard and Yale are obviously national law schools and even globally respected institutions. Others sit at different points on the reputational continuum even to the point of being "local" educational institutions that primarily serve the needs of a closed employment and educational market. Even on that level, there are distinct competitive conditions created by demographics, an area's economic dynamism or lack thereof, employment viability, and applicant demand as well as selectivity and cost.

For law schools of an essentially local competitive character, the numbers are bleak. At a minimum, there will be a dramatic transformation of their operational context and the possibility that the law job market in the sectors to which they have access will implode. Of the $1,180,386$ lawyers nationally in 2009, 581,762 were located in seven states (New York, California, Texas, Florida, Illinois, Massachusetts and New Jersey). ${ }^{23}$ This represents almost fifty percent of US lawyers. Of those states, Illinois experienced a loss of almost 3000 lawyers during the year period while Massachusetts gained only $697 .{ }^{24}$

The top states (New York, California, Texas and Florida) saw a net increase of 7,654 lawyers between 2008 and 2009..25 This data suggests strongly that the Sunbelt and coastal states along with the urban corridor of the Northeast are at least experiencing a competitive situation where they can "hold their own," even while "local" market law schools in the Midwest and rural regions cannot realistically expect to sustain their historical positions as they face dramatic and powerful competitive forces. Such schools can survive and several may even prosper but not in the form and cost structures in which they currently exist.

National law schools like Harvard, Yale, Stanford, Michigan, Chicago, et al. who sit at the pinnacle of the law school "food chain," will feel only a relatively slight impact and this analysis has little to say to such institutions. Mid-range and lower-range law schools, regardless of whether they are privately or publicly funded, will experience the primary impacts of the

Laura A. Bischoff, Each Ohio county sets its own pay scale for appointed attorneys, DAYTON DAILY NEwS (March 6, 2010), http://www.daytondailynews.com/news/dayton-news/eachohio-county-sets-its-own-pay-scale-for-appointed-attorneys-584320.html; see also Stephen Gillers, The Double Standard: Inequality in Criminal Justice May Be a Good Thing for the Favored Classes, N.Y. Times Book REV., Mar. 21, 1999, at A13; David Cole, No EQual Justice: RaCe \& Class in the AmeriCan Criminal Justice SyStem (1999); Marcia Coyle, Death Defense is a Sham: Claim is Fla. Provides Lawyers but Makes It so They Can't Save Inmates, NAT'L L. J. Monday, December 21, 1998 at Al.

23. See infra Part III (providing data and accompanying notes relating to lawyer population on a state-by-state basis).

24. Id.

25. Id. 
increasingly intense competitive conditions. Very substantial effects will be experienced at the run-of-the-mill private law schools whose tuition has grown to levels between $\$ 40,000$ and $\$ 50,000$ per year accompanied by living costs and incidental expenses that add another $\$ 12,000-\$ 15,000$ to the annual cost. ${ }^{26}$

Even though many private law schools will be affected negatively, publicly funded law schools will also be dramatically affected. ${ }^{27}$ This is due to declining state budgets and competition for scarce resources from areas of public expenditure with far more powerful lobbying support and, in fairness, greater and more demonstrable and immediate needs. ${ }^{28}$ For publicly funded law schools, there is significant danger in the fact that there is no shortage of lawyers in America after decades of rapid expansion.

One conclusion would appear to be that, with many recent law graduates having great difficulty finding employment, there should be increased restrictions on the numbers of law students admitted to traditional law schools. Even if the law schools do not cut back on students, it is likely that some states will decide there at least should be a reduced or even no

26. A recent report concluded that a significant number of law students were graduating with at least $\$ 120,000$ in educational debt. See Paul L. Caron, 46\%-60\% of Law School Class of 2013 Will Graduate With \$120k Debt, TAXProf Blog (Jan. 15, 2009), http://taxprof.typepad.com/taxprof_blog/2010/01/4660-of-law-.html.

27. See Riya Bhattacharjee, UC Starts Year With 8 Percent Course Cut, Layoffs, THE BERKELEY DAILY Planet, Aug. 27, 2009, at 2, available at http://www.berkeleydailyplanet.com/issue/2009-08-27/article/33615?headline=UC-Starts-

Year-With-8-Percent-Course-Cut-Layoffs ("Budget cuts, furloughs, layoffs and course reductions dominated the UC Berkeley Chancellor's Back-to-School briefing Wednesday, as students trooped back to school for the first day of fall classes. . . . [UC Berkeley Chancellor Robert] Birgeneau said the university learned in late May that there would be an additional $\$ 80$ million shortfall for the year starting July 1, bringing the total budget deficit to $\$ 150$ million and sending campus officials scrambling to find new ways to address the cuts. 'We had a budget plan we thought would work,' Birgeneau said, 'but the news from Sacramento changed that.' Birgeneau said the cuts meant that the state was essentially providing zero dollars for 9,000 students.").

28. See Paul L. Caron, University of California Faculty Face 4\%-10\% Pay Cut, TAXPROF BLOG (July 11, 2009), http://taxprof.typepad.com/taxprof_blog/2009/07/universityof-california-faculty.html; Larry Gordon, UC President Outlines Revised Budget-Cutting Proposal, L.A. Now (July 1, 2009), http://latimesblogs.latimes.com/lanow/2009/07/ucpresident-outlines-budget-cutting-proposal.html ("Most University of California professors and staff would be forced to take between 11 and 26 unpaid furlough days a year-cutting their paychecks between $4 \%$ and $10 \%$ under a revised budget reduction proposal presented today by UC President Mark G. Yudof."); Paul L. Caron, Wisconsin Orders Faculty Not to Work During 16-Day Furlough, TAXPROF BLOG (July 10, 2009), http://taxprof.typepad.com/ taxprof_blog/2009/07/wisconsin-orders-faculty-not-to-work-during-mandatory-16day-

furlough-.html ("The Governor's furlough mandate, established in response to the State's projected budget shortfall, requires an effective cut in pay for all full-time, 12-month employees equivalent to 16 days over the two-year period July 1, 2009 through June 30, 2011. . .. The mandatory furloughs result in a $3.065 \%$ annual pay reduction."). 
public subsidy for educating students for employment areas such as law where there is no demonstrable demand. ${ }^{29}$

Contrary to the decline in demand for their "output," American law schools continue to expand in the number of institutions and graduates and have "pumped" new lawyers into the system in steadily growing numbers. ${ }^{30}$

29. One solution in the LA Times suggests that the ABA be stripped of its accreditation role entirely and that power be placed in the Association of American Law Schools (AALS).

The $[A B A]$ allows unneeded new law schools to open and refuses to regulate them. ... [T]housands of lawyers now find themselves drowning in the unemployment line as the legal sector is being badly saturated with attorneys.

Part of the problem can be traced to the [ABA], which continues to allow unneeded new schools to open and refuses to properly regulate the schools, many of which release numbers that paint an overly rosy picture of employment prospects for their recent graduates. There is a finite number of jobs for lawyers, and this continual flood of graduates only suppresses wages. Because the ABA has repeatedly signaled its unwillingness to adapt to this changing reality, the federal government should consider taking steps to stop the rapid flow of attorneys into a marketplace that cannot sustain them. ... The American Dental [Association], the nation's leading dental group, offers a model for the ABA to follow. It accredits schools but assiduously guards the profession and has allowed respected dental schools such as the ones at Emory, Georgetown and Northwestern to close for economic reasons and to prevent market saturation. Such a move by the bar association would be unprecedented. Dental schools go even further to protect the profession's integrity by collectively boycotting the U.S. News rankings.

The U.S. Department of Education should strip the ABA of its accreditor status and give the authority to an organization that is free of conflicts of interest, such as the [Association] of American Law Schools or a new group.

Mark Greenbaum, Op-Ed., No More Room at the Bench, L.A. Times (Jan. 8, 2010), http://articles.latimes.com/2010/jan/08/opinion/la-oe-greenbaum8-2010jan08.

30. See Am. Bar Ass'N, ENROllment AND DEgreEs AWARded 1963-2008 1, http://www.abanet.org/legaled/statistics/charts/stats\%20-\%201.pdf (last visited Oct. 30, 2010) [hereinafter ENROLLMENT AND DEGREES AwARDED] for growth in law schools and enrollment. In 2008-2009, there were 200 law schools with 49,414 1st year students enrolled; 142,922 students were seeking a JD degree; total enrollment was 152,033 ; and $43,588 \mathrm{JD}$ degrees were awarded. Id. The data that follow for the other years selected reflect the trend in growth. In 2004-2005, there were 188 law schools with 48,239 1st year students enrolled; 140,376 students were seeking a ID degree; total enrollment was 148,169; and 40,023 JD degrees were awarded. In 2000-2001, there were 183 law schools with 43,518 1st year students enrolled; 125,173 students were seeking a JD degree; total enrollment was 132,464; and 38,157 JD degrees were awarded. In 1974-1975, there were 157 law schools with 38,074 1st year students enrolled; 105,708 students were seeking a JD degree; total enrollment was 110,713; and 28,729 JD degrees were awarded. In 1969-1970, there were 144 law schools with 29,128 1st year students enrolled; 64,416 students were seeking a JD degree; total enrollment was 68,386; and 16,733 JD degrees were awarded. In 19631964 , there were 135 law schools with 20,776 lst year students enrolled; 46,666 students 
In three years covering 2005-2008, the schools processed the following numbers of students: in 2005-2006, 140,298 students; in 2006-2007, 141,031 students, and in 2007-2008, 141,719 students. ${ }^{31}$ Each year more than 40,000 new lawyers were added to an already saturated employment market. ${ }^{32}$ This growth has placed extreme pressures on the competition for fees from clients able to pay. It has also produced intense competition for scarce jobs of quality and stability, although in the new world of employment stability is itself an increasingly ephemeral term. ${ }^{33}$

A study of educational debt incurred by recent law graduates completed in 2003 by the ABA Commission on Loan Repayment and Forgiveness concluded that the debt load on graduation from law school prevents many new graduates from pursuing public service careers. ${ }^{34}$ The 2003 study found that law students graduate with an average educational debt of $\$ 80,000 .^{35}$ More than twenty percent of graduating students have an excess of $\$ 100,000$ of debt. ${ }^{36}$ The study also estimates the median public interest legal salary is about $\$ 36,000$ and that the average monthly loan payment is $\$ 1,100 .{ }^{37}$ One writer compares law graduates' debt load to a home mortgage, with the total cost of a three-year law school education potentially

were seeking a JD degree; total enrollment was 49,552; and 9,638 JD degrees were awarded. Id. at 1-2.

31. Id.

32. See id.

33. The ABA Section of Legal Education and Admission to the Bar reported the following Fall 2007 Law School Enrollment Statistics:

- Total Law School Enrollment: 149,745 (up 0.7\% from 2006)

- Total J.D. Enrollment: 141,433 (up 0.3\%)

○ Male: $75,383(53.2 \%$ ) (up 0.6\%); Female: 6,050 (46.8\%) (down 0.1\%)

- Minority: 30,598 (21.6\%) (up 0.1\%)

- Total First Year J.D. Enrollment (up 0.1\%)

○ Male: $25,799(52.7 \%$ ) (down 2.0\%); Female: 23,165 (47.3\%) (up 2.4\%)

o Minority: 10,992 (22.4\%) (up $0.9 \%$ ).

Paul L. Caron, Fall 2007 Law School Enrollment Data, TAXProf Blog (Feb. 19, 2008), http://taxprof.typepad.com/taxprof_blog/2008/02/fall-2007-law-s.html; Press Release, American Bar Association, Law School Enrollment Statistics Show Only Slight Changes (Mar. 4, 2008), http://www.abanet.org/abanet/media/release/news_release.cfm?releaseid $=268$ (last visited Dec. 30, 2010).

34. Am. Bar Ass'n, Lifting the Burden: Law Student Debt as a BarRier to PUBLIC SeRvice 10-11 (2003), available at http://www.abanet.org/legalservices/ downloads/Irap/lrapfinalreport.pdf [hereinafter LIFTING THE BURDEN].

35. LifTING THE BURDEN, $i d$, at 9-10, 14.

36. Id. at 24 .

37. See, e.g., Michelle Porter, Law School Students and the Burden of Debt, N.C. LAw., available at http://www.ncbar.org/about/communications/nc-lawyer/2005-nc-lawyereditions/septemberoctober-2005/law-school-students-and-the-burden-of-debt.aspx; LIFTING THE BURDEN, supra note 34, at 9-10, 18. 
reaching $\$ 150,000$, according to estimates from the Law School Admission Council. $^{38}$

In 1992, the average total of tuition and fees at public law schools in the U.S. was stated by ABA data as being $\$ 4,015$ for residents and $\$ 9,070$ for non-residents. ${ }^{39}$ By 2006 , that figure had increased to $\$ 14,245$ and $\$ 25,227.40$ The costs are dramatically higher for private law schools. At private law schools the 1992 average for tuition and fees was $\$ 13,730$. 11 By 2006 , that average was $\$ 30,520 .^{42}$ The result is that the average amount a U.S. law student has borrowed for law school is over $\$ 80,000$ for private law school students and $\$ 54,000$ for public law students. ${ }^{43}$

In the face of such numbers, one might expect the law schools to reduce admissions to legal education, but instead there has been an increase in not only the number of new graduates, but an increase in the number of law schools. $^{44}$ In 2006, 43,883 Juris Doctor degrees were awarded, an increase from 37,909 in $2002 .{ }^{45}$ Not only were the gross numbers increasing, but the number of law schools increased by eleven percent since 1995 . $^{46}$ The September 2009 edition of The National Jurist further reports that ten new law

38. Id.

39. Law School Tuition 1985-2008, AM. BAR. Ass'N., 1-2, http://www.abanet.org/ legaled/statistics/charts/stats\%20-\%205.pdf (last visited Oct. 30, 2010) [hereinafter Law School Tuition].

40. Id.

41. Id. at 3 .

42. Id.

43. Average Amount Borrowed for Law School 2001-2008, AM. BAR Ass'N., http://www.abanet.org/legaled/statistics/charts/stats\%20-\%2020.pdf (last visited Oct. 30, 2010); see generally Most Law Graduates Dissappointed [sic]: Few Jobs, Low Salaries, High Stress, L. STUDENT (Nov. 23, 2007), http://www.lawstudent.tv/2007/11/23/most-lawgraduates-dissappointed-few-jobs-low-salaries-high-stress/ (last visited Oct. 30, 2010) ("There seems to be a growing problem among law school graduates and new attorneys. They can't find law jobs, the jobs they find don't pay enough to repay law school loans, and the jobs require unhealthy amounts of hours doing the type of work that many lawyers find unsatisfying, or worse. The number of law school graduates continues to increase must [sic] faster than the number of law jobs available. The supply of law graduates is high, but the demand has not kept pace. As a result, law school graduates who did not graduate in the top $10 \%$ of a Tier 1 law school are having great difficulty getting a job in law that pays enough to pay off their law school loans. Further, even those law graduates who find jobs are often unhappy with the practice of law and the high number of hours they must spend at the firm.").

44. ENRollment AND Degrees Awarded, supra note 30, at 1. The ABA Section on Legal Education and Admission to the Bar Fall 2007-2008 Law School Enrollment Statistics were as follows: Total Law School Enrollment: 150,031 (up 0.88\% from 2006); Total J.D. Enrollment: 141,719 (up 0.48\%); Total First Year J.D. Enrollment: 49,082 (up 0.29\%). Id.

45. Amir Efrati, Hard Case: Job Market Wants for U.S. Lawyers, WaLL ST. J., Sept. 24, 2007, at A1, available at http://global.factiva.com.proxyl.cl.msu.edu/ha/default.aspx.

46. Id. 
schools are "in the works". ${ }^{47}$ As counter-intuitive as this seems, we can understand the fact that with good jobs increasingly scarce in many fields and with the ability to continue borrowing on student loans for graduate education, many law school applicants are hoping that obtaining a law degree will provide them with an advantage they will otherwise not possess. "Hope springs eternal," and law school applicants are faced with negative employment and earnings alternatives that are still causing many to "roll the dice" represented by the increasingly false promise of legal education in the hope they will be the ones who hit the jackpot.

The relationship between the organized bar as represented by the $\mathrm{ABA}$, state supreme courts, and the university law schools also allowed the organized bar to acquire the power of control over entry into the privilege of being a lawyer through the power of accreditation. ${ }^{48}$ The result is a rigid system of often inadequate education from the perspective of the skills and knowledge needed to be an effective lawyer even while imposing a very expensive rite of passage into the legal profession.

This system traditionally worked to the financial advantage of lawyers by controlling the number of competitors coming into the legal profession, but can be criticized for its lack of imagination, lack of relevance to law practice, and high cost. In any event, the law schools have expanded so dramatically over the past two decades that the economic and budgetary transformations we are experiencing have altered the system radically.

Among the most important effects that we are already beginning to see is a change in the level of tolerance that has allowed the combination of law schools, the ABA, and state-by-state supreme court monopolies over legal education and admission to the bar. The ABA's role in accreditation has been questioned. Whatever its historical justification in a legal environment where law practice was essentially local and small scale, and access to practice information often limited and esoteric, the simple fact is that law practice in an Information Age has far transcended localized boundaries.

47. Rebecca Larsen, 10 New Law Schools in the Works, NAT'L JURIST, Sept. 2009, at 12. The schools are in various stages of development and are: University of California, Irvine; Concordia University (Idaho); Louisiana College; Lincoln Memorial University (Knoxville, Tenn.); St. John Fisher College (Rochester, NY); SUNY Binghamton; Wilkes University (Wilkes-Barre, Pa.); SUNY Stony Brook; University of New Haven; and Husson College (Bangor, Me.). Id. at 13. The plans include schools set to open as well as others that have been suspended due to state budget issues. The two proposed SUNY system law schools have been opposed as unnecessary by SUNY Buffalo law school. Id. at 12 .

48. See generally Barnhizer, The University Ideal, supra note 4 (noting the system operates mainly through the ABA's Section of Legal Education and Admission to the Bar whose members includes lawyers, law deans and judges and that the Section is both formulator and gatekeeper of the system that sets accreditation standards). 
The state-by-state bar admission rules are entry barriers that protect lawyers in Ohio, Michigan, California and other states from competition. ${ }^{49}$ Law school curricula are virtually identical. The course materials produced by publishers such as Aspen and West are used in nearly all law courses across the nation. The teaching methods used in law schools are essentially indistinguishable. The Multi-State Professional Responsibility Examination (MPRE) and Multi-State Bar Examination are taken by aspirants in essentially all states. Essays written on the different state bar exams cover the same material learned in identical courses in law schools using the same array of texts regardless of law school attended. With these characteristics providing the educational and testing processes for law students, there is no significant justification for requiring state-by-state admission rather than a national bar exam that would allow successful takers to practice in any jurisdiction.

Implications for the immediate future for law schools include the fact that there is no discernible "magic" to the existing structure of legal education in the U.S. While the schools have been largely insulated from public scrutiny by their connection to the ABA and status as parts of the university institution, this protective "covering" will be removed over the next five to ten years if not sooner. The result for many law schools is that unless they learn to adapt to the changed conditions and still declining demand for lawyers as that job is traditionally conceived, some law schools will shrink dramatically. Others will disappear in the face of hardened and unforgiving competitive conditions. ${ }^{50}$

Nor are U.S. law schools well-positioned to prove their quality or necessity in the face of knowledgeable critics. There has been no comparative "value-added" analysis of the relative benefits gained by the American model in which law graduates are required to complete a university degree and then take a three or four year graduate program in law school prior to sitting for admission to the bar. There is also no empirical basis that establishes the quality of services provided Americans by lawyers as a body in exclusive control of the provision of legal services. Much of the technical

49. See, National Conference of Bar Examiners and American Bar Association Section of Legal Education and Admission to the Bar, Comprehensive Guide to Bar Admission Standards 2010, NCBEX.ORG, http://www.ncbex.org/fileadmin/mediafiles /downloads/Comp_Guide/CompGuide_2010.pdf (last visited Jan. 17, 2011).

50. Joan Howarth, Dean of Michigan State University College of Law, suggests that the current move, led by the National Council of Bar Examiners (NCBE), for a uniform bar exam seems very relevant here. Dean Howarth states, "the issue of whether state specific law should be tested (as Michigan does significantly) should be evaluated on consumer protection grounds, not conformity to current law school or bar examiner practices." E-mail from Joan Howarth, Dean, Michigan State College of Law, to David Barnhizer (Nov. 14, $2009,11: 12: 43$ EST) (on file with author) (containing Howarth's comments on an earlier draft of this Article). 
work done by lawyers can most likely be done equally well by people who did not attend law school. Indeed, paralegals and law students are already doing much of lawyers' work, albeit theoretically working under a lawyer's supervision. ${ }^{51}$ Pressures for dramatic changes are likely to come at law schools from both the public and private sectors.

Certainly the benefit of the expensive American approach required to become a lawyer cannot be determined through reference to the quality of the legal work produced by lawyers trained in that model contrasted with possible alternative approaches. Nonetheless, most U.S. law schools can be expected to adhere to their current model unless external rules or competitive conditions force changes. The only way this external pressure can occur is to require a fundamental rethinking of the accreditation power from the American Bar Association that at a minimum allows experimentation with a variety of educational strategies and institutional forms. The U.S. Department of Education has been looking at this issue for the past several years much to the dismay of the ABA and the Association of American Law Schools (AALS). ${ }^{52}$

There is, however, no clear and obvious solution. Unless accreditation of law schools was completely eliminated, and I am not arguing that this should occur, some entity must fill the role. Otherwise there can be no doubt that "rip off" programs would emerge as they have in technical education generally that would offer no real benefit while skimming money from students who are either naïve or who desire to take the path of least resistance in becoming licensed to offer legal services. Removing the ABA would mean replacing it with another accrediting institution. That in itself would possibly inhibit rather than invite experimentation. The accreditation changes now underway in the $\mathrm{ABA}$ should be used to more reliably encourage and facilitate experimentation.

\section{ACtive AND RESIDENT LAWYER Population by SElECted STates}

It is important to grasp the reality of the system as it now exists. We are addressing the forces and dynamics of the production scale of law schools measured against the demand for new lawyers and the ability of the job market to absorb the output of the law schools. One way to do this, admittedly crude because there are multiple variables, is to offer a "snap-

51. See, e.g., the discussion of directly supervised and independent paralegals in Unauthorized Practice of Law, NATIONAL ASSOCIATION OF PARALEGAL ASSOCIATIONS, supra note 13.

52. Mark Hansen, ABA Task Force Hears Alternatives to Law School Accreditation Role \#ABAChicago, ABA JOURNAL (July 29, 2009), http://www.abajournal.com/news /article/aba_task_force_hears_alternatives_to_law_school_accreditation_role_abachica/; Department of Education Reviews ABA Law School Accreditation Standards, FEDERALIST SOCIETY, (July 16, 2008), http://www.fed-soc.org/publications /pubid.1133/pub_detail.asp. 
shot" of the lawyers on a state-by-state basis over a period of time. Then we can begin to understand demand in a context of whether we are dealing with a "growth" state or some other lesser economic pattern.

The numbers below are separated by two considerations. The data for the first five states present the situation in Ohio and the four abutting states from which we can expect significant job competition for employment in the pool of available lawyer positions. Of course, this is a simplistic measure because the various niches of legal employment draw from particular law schools. It is a given, for example, that a substantial number of positions in the largest and most prestigious firms come from "national" and regional schools rather than the "local" law schools that occupy the third or fourth tiers of the generally accepted rankings. This means that perhaps as much as fifty percent of the hiring in many large firms is not open to local competitors. The active and resident lawyer population is as follows:

$\begin{array}{llll} & 2008 & 2009 & \begin{array}{l}\text { Net Lawyer } \\ \text { Gain or Loss }\end{array} \\ \text { Ohio } & 36,644 & 37,467 & 823 \\ \text { Michigan } & 32,131 & 32,321 & 190 \\ \text { Indiana } & 13,564 & 14,379 & 815 \\ \text { Pennsylvania } & 46,065 & 46,276 & 211 \\ \text { Kentucky } & 11,876 & 12,088 & 212 \\ \text { New York } & 150,542 & 153,552 & 3,010 \\ \text { California } & 148,399 & 149,982 & 1,583 \\ \text { Texas } & 73,505 & 75,087 & 1,582 \\ \text { Florida } & 59,953 & 61,426 & 1,473 \\ \text { Illinois } & 61,259 & 58,457 & -2,802[\text { loss] } \\ \text { Massachusetts } & 42,501 & 43,198 & 697 \\ \text { New Jersey } & 39,384 & 40,060 & 676 \\ \text { Georgia } & 27,227 & 27,457 & 230 \\ \text { Missouri } & 22,602 & 23,362 & 760 \\ \text { Washington } & 22,276 & 22,973 & 697 \\ \text { Minnesota } & 21,944 & 22,448 & 504 \\ \text { Virginia } & 21,183 & 21,682 & 499 \\ \text { Maryland } & 20,996 & 21,554 & 558 \\ \text { Connecticut } & 19,013 & 19,427 & 414 \\ \text { North Carolina } & 18,966 & 19,637 & 671 \\ \text { Tennessee } & 15,199 & 15,855 & 656 \\ \text { Wisconsin } & 14,448 & 14,906 & 458 \\ \text { Oklahoma } & 12,357 & 11,511 & -846[\text { loss] } \\ \text { Iowa } & 6,959 & 7,036 & 77 \\ \text { Mississippi } & 6,723 & 6,748 & 25 \\ \text { Nevada } & 6,105 & 6,395 & 290 \\ \text { New Mexico } & 5,267 & 5,542 & 275 \\ & & & \end{array}$




$\begin{array}{llll}\text { West Virginia } & 4,618 & 4,672 & 54 \\ \text { Rhode Island } & 4,055 & 4,044 & -11 \text { [loss] } \\ \text { Idaho } & 3,330 & 3,221 & -109[\text { loss] } \\ \text { Alaska } & 2,385 & 2,362 & -23 \text { [loss] } \\ \text { Vermont } & 2,183 & 2,185 & 2 \\ \text { Wyoming } & 1,537 & 1,522 & -15[\text { loss] }\end{array}$

\section{LAW SCHOOLS' New LaWyer Production}

State-funded law schools will face some of the greatest challenges, particularly schools in a state such as Ohio in which there are five statefunded law schools and four private law schools in a state with a declining population, eroding economy, heavily challenged state budget, other expanding budgetary obligations, and a saturated legal job market. Territorial proximity and reputational equivalence will also play significant parts in determining competitiveness. In Northeast Ohio, for example, where two (more realistically three) of the schools [Cleveland State, Akron and Case Western Reserve University (CWRU)] compete in a geographic area only thirty-five miles apart for the same kinds of students, can expect to face hard questions about their strategies for adaptation if they want to survive. ${ }^{54}$

Similarly, the four private Ohio law schools [CWRU, Capital, Ohio Northern and Dayton] can be expected to face increased challenges to their survival. This is due to the combination of their high cost, difficulties in graduates finding employment as the legal job market continues to decline, and the relatively intractable personnel and expense structure and vision of the university law school as being a center of important intellectual productivity and research by law faculty.

The competitive situation is likely to be even worse for intermediate and lower-ranked private law schools that charge high tuitions of around $\$ 35,000$ to $\$ 45,000$ per year. They will have to address questions about the

53. See Am. Bar Ass'N, National Lawyer Population by State 4 (2009) [hereinafter NATIONAL LAWYER POPULATION], available at http://www.abanet.org/marketre search/resource.html (click on National Lawyer Population by State).

54. The consequences are not limited to the Rust Belt law schools. See, e.g., UC Law School Profs Hit by Pay Cut, JDJournal (July 27, 2009), http://www.jdjournal.com/2009/07/27/uc-law-school-profs-hit-by-pay-cut/ ("The University of California has announced a furloughs scheme beginning in September, affecting faculty at law schools, amongst others. The system is effectively slashing salaries by $4 \% 10 \%$. The plan requires faculty and staff to take up to 26 unpaid furlough days during the 2009-10 school year. One hundred and eight thousand employees of the UC system will be affected. At UCLA Law, 60 law faculty members and 100 law school staff members face furloughs, as do 35 faculty members and 75 staff members at UC Davis' Law School. The UC Irvine School of Law, which opens this fall with its first incoming class, will see 17 faculty affected. The UC Board of Regents is facing a $20 \%$ cut in money from the state's general fund."). 
"value added" contributions they offer relative to publicly-funded institutions whose costs may be only a third of that required for the private schools. In many instances, they will not be able to justify the radically different expenditures. This will offer a competitive buffer for public law schools that increasingly attract students who would previously have opted for the intermediate-ranked private law schools.

This indicates that some of the harshest competitive effects will be experienced by intermediate and lower-ranked private law schools with high costs and which must increasingly compete with publicly-funded competitors located in territorial proximity. These law schools will, in many instances, find that the bottom has fallen out of their applicant markets and experience a rapid plummeting of revenues to the point of staff and faculty layoffs, and even closure. This will occur partly due to an overall decline in enrollments, but even more to the fact that public and private law schools further up the "pecking order" will attract their students as the system as a whole makes competitive adjustments. The message has to be: the system will not stay the same, and cannot stay the same, and should not stay the same. Change is indeed coming on a variety of fronts and it will not be a pleasant experience for many law schools and law faculties.

One example of how different law schools will be affected is that law schools located in states in which they are the only institution educating lawyers can be expected to experience fewer problems than those in areas where there are numerous schools chasing applicants for a shrinking "pie." The University of New Mexico, for example, a small state-funded law school with no in-state competitors, can be expected to adapt well to the competitive pressures and to be buffered against external competition. The same might be said for the public law schools of Wyoming, Idaho, Colorado, Arizona, Utah, and possibly Nevada. The University of Nevada, Las Vegas (UNLV) law school is already a prominent part of the legal culture of Nevada and can be expected to occupy a protected category even with the economic downturn that has afflicted that state..$^{55}$ Brigham Young University (BYU) and the University of Utah are likely to experience a growing competitive tension given the unique culture of that state, although the private nature of BYU and its special treatment of students who are members of the Mormon Church (50 percent general tuition) reflect a special competitive niche for that institution.

But many of the 50 law schools in states such as Ohio (10), Michigan (5), Pennsylvania (7), New York (15), Indiana (4) and Illinois (9)-with static or declining population bases and troubled economies with rising social expenditures - can expect to face very significant challenges. If we

55. E-mail from Joan Howarth, supra note 50 (Dean Howarth is the dean of Michigan State University College of Law and is a former UNLV faculty member). 
count the University of Northern Kentucky (located immediately across the Ohio River from Cincinnati) as essentially an Ohio law school, Ohio has ten law schools serving a static or declining population-base with an eroding economic foundation and a state budget that at best can be described as "troubled" and may be better understood as requiring "life support." ${ }^{56}$ Hard decisions are necessary in Ohio and the surrounding states, and it would be far better for law schools to engage in intelligent strategic planning that "gets ahead of the curve" than to be the blind and rudderless victims of the economic, accreditation, and competitive trends.

The ten Ohio law schools enrolled 5,337 aspiring law students and in 2008 awarded 1,600 Juris Doctor degrees. ${ }^{57}$ Even that does not begin to tell the full story. Law schools serve different applicant and employment markets. While Ohio State and Cincinnati can be viewed as either mid-national or at least regional law schools with Case having some vestigial claim to that status, the remaining Ohio law schools are either "local" or caught within an applicant and employment territory that extends only slightly beyond the state's borders.

This does not mean that some graduates from the less grand law schools do not "go national" in terms of the employment they obtain or that some students do not enroll in those "local" schools from farther distances. Nor does it mean that the quality of education, as opposed to reputation in what is undeniably an elitist hierarchical system of ranking law schools on historical tradition that is not truly merit-based, is necessarily any less. But we are speaking of competitive realities and the reality is that the applicant and employment markets within which most of the Ohio schools operate, are forced to operate, and will continue to operate for the "marketing" of their products and the attraction of new applicants are firmly bounded by territory and historical reputation. It is not a malleable or flexible system. This means that strategic and competitive options are limited.

56. See Kasich Ohio budget cuts, AMERICAN NEwS Now, http://www.american newsnow.com/2010/10/info-kasich-ohio-budget-cuts.html (last visited Jan. 17, 2011).

57. University of Akron School of Law: Enrollment: 488/JD Degrees awarded: 148 Capital University Law School: 651/184

Case Western Reserve University School of Law: 658/214

University of Cincinnati College of Law: 361/122

Cleveland State University — Cleveland-Marshall College of Law: 666/203

University of Dayton School of Law: 479/126

Northern Kentucky University-Salmon P. Chase College of Law: 571/156

Ohio Northern University_Claude W. Pettit College of Law: 309/94

Ohio State University Moritz College of Law: 670/210

The University of Toledo College of Law: 494/143

LAw SCH. Admission COUNCIL \& AM. Bar ASs'N, ABA-LSAC Official Guide to ABAAPPROVED LAW SCHOOLS 76, 176, 184, 212, 220, 244, 540, 556, 560, 760 (2010 ed. 2009). The total number enrolled in these ten law schools in 2008 was 5347 . The number of JD Degrees awarded by these ten law schools in 2008 was 1600 . Id. 
The challenge of being restricted to competitive "localism" is heightened because Ohio law schools do not have the Ohio market to themselves. Even if we don't count the top national law schools as dominant and preferred competitors for their graduates for the "plum" law firm jobs at the high paying corporate firms (that are themselves cutting back), there are another ten law schools operating within what can be considered the "local" competitive territory of the Ohio schools. These law schools abut the state and vie for applicants and employment opportunities for their graduates. They include: University of Buffalo (SUNY), University of Detroit Mercy, Thomas M. Cooley, Duquesne University, Indiana University (Indianapolis), The University of Michigan, Michigan State University, Notre Dame, University of Pittsburgh and Wayne State University. Rather amazingly, these ten law schools enrolled 10,770 students and awarded 3,098 Juris Doctor degrees in $2008 .^{58}$

The result is that twenty law schools located roughly within a 300 mile radius, at least fifteen of which are arguably competing on essentially the same levels in terms of applicants and employment opportunities for their graduates, enrolled 16,107 law students and granted almost 5,000 Juris Doctor degrees $(4,698)$ in 2008 , entitling their graduates to take the bar and enter the increasingly harsh world of the legal profession. Note that all these schools are located in states with declining economic bases and static populations with state budgets under significant pressure and post-law school employment opportunities questionable at best. This list includes one national law school at the University of Michigan whose graduates have the greater reputational flexibility needed to obtain jobs beyond the area, and Notre Dame, which is at least a strong regional school. The others, with

58. See id.

Geographical Competitors:

University of Buffalo Law School: Enrollment: 745/JD Degrees awarded: 237

The Thomas M. Cooley Law School: 3,678/845 (with 3,239 part-time students and 1,903 first year students)

University of Detroit Mercy Law School: 736/221

Duquesne University School of Law: 703/154

Indiana University School of Law (Indianapolis): 953/283

The University of Michigan: 1,151/387

Michigan State University College of Law: $955 / 319$

Notre Dame Law School: 558/186

University of Pittsburgh School of Law: 698/240

Wayne State University Law School: 593/226

The total enrolled in the above ten law schools that compete geographically with the Ohio schools was 10,770. The JD Degrees awarded by these ten law schools in 2008 was 3098 . Id. at $148,256,276,384,464,468,548,600,752,820$. 
the exception of Cooley, ${ }^{59}$ are competitively similar and essentially competing against each other to some degree.

An obvious dilemma is caused by the fact that most of the Ohio law schools are essentially local. After the limited number of "elite" graduates (top ten to twenty students depending on the reputation of the law school, law review editorship and possible federal judicial clerkships) who are admitted to the world of the large law firm, the law schools in this category have a very significant portion of their graduates competing for the same pool of available law jobs in a finite and bounded geographic area. The top paying corporate firm positions are dominated by graduates of the national schools and the thin tier of top graduates from the intermediate institutions. ${ }^{60}$ As demonstrated by the data, the Ohio law schools also find themselves surrounded by ten other schools producing twice as many graduates annually. Many of those graduates are pursuing the same employment pool. This means that the absolute number of legal positions available dictates whether those fifteen or sixteen "local" law schools can place their "products" after graduation.

The fact that the schools cannot "sell" their "products" is indicated by data produced by the ABA Research Center representing the distribution of lawyers by state. I selected a comparison between 2008 and 2009. ${ }^{61}$ The total U.S. lawyer population indicated by the ABA Research Center is $1,162,124$ for 2008 and $1,180,386$ for 2009 , a net national change of 18,262 in that period. ${ }^{62}$ The data are particularly interesting when they reveal an increase of 823 lawyers at a time when the ten law schools being counted as Ohio schools awarded 1,600 Juris Doctor degrees and the closest law schools just across Ohio's borders granted another 3,098 J.D. degrees for a total of nearly 5,000 new graduates in the period. ${ }^{63}$

Of course there will have been some retirements and deaths, but one might suspect that such departures from the legal profession do not make up the gap between employment and aspirants. The data set out above also

59. Although it is only one critic's opinion, a scathing assessment of Cooley can be found at Michael Kraemer, Thomas Cooley Law School is an Embarrassment, THE POLITICAL CARTEL FOUNDATION (March 3, 2010), http://politicalcartel.org/2010/03/ 03/thomas-cooley-law-school-is-an-embarrassment.

60. The situation relating to who gets a fair shot at jobs based on merit rather than bias and prestige is even worse than generally thought. See, e.g., Tom Bartlett, Brown and Cornell are Second Tier, Chronicle of Higher EduCATION (January 7, 2011), http://chronicle.com/blogs/percolator/brown-and-cornell-are-second-tier/27565. The report states: "What's surprising isn't that students from elite universities have a leg up; it's that students from other colleges don't have a chance, even if those colleges are what the rest of us might consider elite." Id.

61. National Lawyer Population, supra note 53.

62. Id.

63. See data on Ohio law schools and neighboring states collected supra notes 57 and 58. 
demonstrate that some states are experiencing declines in the lawyer population, others only minimal growth, and that significant growth is only occurring in the South and the most productive urban areas.

\section{SOBERING MARKET INFORMATION RELATED TO THE LEGAL PROFESSION}

A Wall Street Journal analysis of the situation offered the following observations:

- "[T]he majority of law-school graduates are suffering from a supply-and-demand imbalance that's suppressing pay and job growth."

- "Graduates who don't score at the top of their class are struggling to find well-paying jobs to make payments on law-school debts that can exceed $\$ 100,000 . "$

- "Some are taking temporary contract work, reviewing documents for as little as $\$ 20$ an hour, without benefits."

- "[M]any [recent graduates] are blaming their law schools for failing to warn them about the dark side of the job market."

- "On the supply end, more lawyers are entering the work force, thanks in part to the accreditation of new law schools and an influx of applicants after the dot-com implosion earlier this decade."

- "In the 2005-06 academic year, 43,883 Juris Doctor degrees were awarded, up from 37,909 for 2001-02."

- "Since 1995, the number of ABA-accredited schools increased by $11 \%$, to $196 . "$

- "Evidence of a squeezed market among the majority of private lawyers in the U.S., who work as sole practitioners or at small firms, is growing. A survey of about 650 Chicago lawyers published in the 2005 book 'Urban Lawyers' found that between 1975 and 1995 the inflation-adjusted average income of the top $25 \%$ of earners, generally big-firm lawyers, grew by $22 \%$-while income for the other $75 \%$ actually dropped."

- "According to the Internal Revenue Service, the inflation-adjusted average income of sole practitioners has been flat since the mid1980s. A recent survey showed that out of nearly 600 lawyers at firms of 10 lawyers or fewer in Indiana, wages for the majority only kept pace with inflation or dropped in real terms over the past five years."

- "Many students 'simply cannot earn enough income after graduation to support the debt they incur,' wrote Richard Matasar, Dean of 
New York Law School, in 2005, concluding that, 'We may be reaching the end of a golden era for law schools." ${ }^{\prime 64}$

The "golden era" to which Dean Matasar refers has already ended for large law firms and 500,000 solo and small law firm practitioners. Many of those law firms are now "downsizing" and cutting loose associates and nonequity partners. A recent report shows that thousands of lawyers are being let go from the large firms-including non-equity partners, senior associates and new lawyers. ${ }^{65}$ This is a situation without precedent, one that is likely to further intensify the competitive pressures for smaller practitioners. As large numbers of talented and aggressive lawyers who no longer have jobs in the big firms enter the competitive markets traditionally reserved for smaller firms and even solo practitioners, this will produce a competitive ripple effect throughout the structure of law practice.

Many lawyers and recent graduates find themselves caught in the shift to "temporary" legal employment. ${ }^{66}$ This transition includes the high value "boutique" firms that engage in specialized business practices. These firms will find numerous and unanticipated competitors willing to provide services at lower prices as they seek to enter the specialized areas of practice blossoming in their dedicated fields. Many law firms and lawyers have already seen some of the changes in an increased shift to temporary or contract law-

64. Efrati, supra note 45.

65. Tresa Baldas, The Layoff List: Employment Shifts at The Am Law 200, Global 100, and other Firms of Note, AM. LAW., May 19, 2010, available at http://www.law.com/jsp/tal/PubArticleTAL.jsp?id=1202425647706.

66. See, e.g., Elie Mystal, Contract Attorneys: Good Work If You Have No Other Option, ABOVETHELAw.COM (JAN. 13, 2009), http://abovethelaw.com/ 2009/01/contract_attorneys_good_work_i.php (Mystal observes: "Back in the golden days of Biglaw (in the before times, in the long, long ago), associates were fired all the time. Getting laid off for poor performance or low hours is nothing new. Of course, back when we had a functional American economy, getting fired was a temporary bump in the road. You could always work at a smaller firm or for the government. Back in the day, you could even work as a contract attorney if you needed something to tide you over. Now ... everything is different. And contract attorney jobs are great gets in this market. . . 'As law firms downsize, laid-off attorneys and new law school graduates unable to find jobs have been turning to an option they may never have imagined at law school: becoming contract attorneys - hired guns for $\$ 35$ an hour. Yet in the past couple of months, even that field appears to be showing signs of a slowdown.' People who waited too long to swallow their pride and confront the reality of the financial crisis are finding that contract work has already been snapped up by less prestige conscious job seekers. And it probably isn't helping that just as the American legal market is starved for low level work, the ABA has made it easier to outsource doc review to other countries: 'Also cutting into their business is the growing popularity of outsourcing to India. Hudson Legal has countered with an ad campaign that encourages law firms to "onshore," and choose U.S. staffing companies where there are no security or privacy concerns and where they operate in the Eastern time zone." (quoting the National Law Journal)). 
yers who are hired for specific cases or functions and are paid considerably less than the large firms pay regular full-time lawyers. ${ }^{67}$

A core aspect of the competitive dilemma is that American law schools have expanded the output of lawyers over the last thirty-five years in a way that, while it may have been consistent with the demand by applicants for entry into law school that justification no longer has any positive connection with the need for lawyers in society. This need is being defined here as the existence of a supply of clients capable of paying for the services of private practitioners and by the numbers of decent paying law jobs that are available for law school graduates. ${ }^{68}$

Michigan State University College of Law Dean Joan Howarth asked in a comment to this Essay: "Do you see any possibility that the confluence of technology transformations and the destabilized legal profession could create a new model of viable decent legal careers serving the currently underserved middle class?"69 My answer is that the combination of technological capability and a destabilized legal profession is a critical driving force for change. The consequences to law schools as presently conceived and the legal profession are, however, likely to be less than benign in terms of their ability to maintain the status quo. An example of how rapid and dra-

67. See, e.g., Jeremy Feiler, Use of Temporary Attorneys Increasing, PHILA. BuS. J. (Apr. 12, 2002), http://www.bizjoumals.com/philadelphia/stories/2002/04/15/newscolumn1 .html ("Late last year [2001], the National Law Journal reported in its annual survey of the country's 250 largest firms that overall growth had ceased for the first time since 1993. 'In an uncertain market where firms have to layoff associates and the like, (temporary attorneys) save costs on recruiting and training associates as well as the costs of having to get rid of them,' [Wade] Bower [, a principal at Newton-Square-based legal consultancy Altman-Weil Inc.] said. Meantime, corporations are trying to keep their legal costs as low as possible, said Jim LaRosa, president of Juristaff Legal Staffing, which specializes in temporary attomey placements. 'The use of contract attorneys on a contract basis is something that is absolutely booming right now,' LaRosa said. 'It cuts across any type of legal department that you can think of.'. . . Bureau of Labor Statistics research indicates the demand for temporary attorneys is growing nationwide. The agency counted about 10,000 temps in 1992 while 40,000 were identified in 1995. By the year 2005 the bureau predicts that demand for temps will rise to $62,400 . ")$.

68. See Nate Raymond, Job Losses in Legal Sector Continue, AMLAW DAILY (Apr. 3, 2009, 11:03 AM), http://amlawdaily.typepad.com/amlawdaily/2009/04/job-losses-in-legalsector-continue.html (Raymond reports: "More than one-third of the legal services jobs created since the 2001 recession have vanished in the current downturn, an analysis of $\mathrm{Bu}$ reau of Labor Statistics data shows. Since the recession began in December 2007, the legal services sector has lost an estimated 24,900 jobs. Those losses continued through March of this year, with legal services employers shedding another 2,700 jobs, according to the latest BLS report released Friday. . . . The 24,900 jobs lost in this recession contrasts with the 72,800 created between November 2001 , when the previous economic downturn ended, and November 2007. That means 34.2 percent of the jobs law firms and other legal services providers created since the dot-com bust have disappeared thanks to the current financial crisis.").

69. Email from Joan Howarth, supra note 50. 
matic the changes could be is provided by computerized research and information systems, sophisticated software applications, paperless court filings and document sharing, and the wonderful invention we call Google. The existence of what only a decade ago would have been seen as an almost magical ability to wave a computer and software-based "wand" and access an unbelievable array of tools and knowledge sources has fundamentally altered much of law practice.

The competitive message is that law practice is not insulated from the technological advances of the kind that have produced labor-saving changes in many other industries. Electronic check-out lines in grocery stores, computer messages, menus when attempting to contact a business telephonically, on-line airplane and travel services that eliminate the travel agent, and ATM machines that create convenience for the users and eliminate bank tellers have resulted in a transformation of the job markets in those industries.

Law practice has not been immune from such developments. The labor intensity of many tasks related to law practice has been reduced due to the computers, software applications and knowledge systems that are now available. As this capacity ripples through the system it takes fewer lawyers to do specific bundles of tasks. This reduces employment options even more than is suggested only by the growth in the absolute number of lawyers. If that impact were not enough to cause problems in the profession, the fact that consumers of legal services now have rapidly expanding access to a great deal of basic and even sophisticated information for which they otherwise had to seek a lawyer's advice can be expected to produce an increasing tendency to "do it yourself" among potential clients.

These changes represent several phenomena. One is that the jobs are not coming back to law firms. The downsizing is not simply a response to our economic downturn, but a consolidation reflecting the impact of significant labor saving technologies on legal tasks. Another factor is that corporations are increasingly able to have access to sophisticated legal information to the extent they can do more things in-house or have internal staff take matters to a point where they are only seeking final validation or input from external counsel.

A third aspect of the availability of information on-line concerning how to do "legal things" in specific areas is that it can be expected to support a frontal assault on rules against the unauthorized practice of law. The on-line material to a significant extent can be viewed as removing the mystery from a great deal of what lawyers do and exposing their secret incantations to others who are capable of filling out forms and filing papers. This could easily extend to areas such as simple bankruptcy and real estate matters but is likely to have impacts far beyond the obvious areas traditionally reserved to licensed lawyers. 
Suggesting that a giant economic engine such as Walmart might decide to open a legal services wing that might be dedicated to either the more traditional services in law offered by actual lawyers or through a challenge to restrictions on the provision of services by paralegals was not intended to be humorous. It requires no leap of imagination to see such institutions deciding to directly challenge the rules on who can own and franchise incorporated law businesses, who is entitled to own or share the profits of law practices, and why lawyers providing basic legal services should have to be admitted in the specific state where Walmart seeks to use the lawyer's services. We might react by laughing and saying "it can't happen here" but it is already happening in the UK and Australia. ${ }^{70}$

On the one hand, there are lawyers making over $\$ 1.3$ million per year in law businesses operating in the form of what we call large law firms. On the other hand, we have the majority of lawyers in one-person businesses we call solo law practice along with quite a few "mom and pop" stores selling "law." The solo and small firm businesses represent roughly 500,000 practitioners of law, two-thirds of all lawyers engaged in the business of private law practice. ${ }^{\prime \prime}$

John P. Heinz and Edward O. Laumann reported in the Chicago Lawyers II study that it is these solo lawyers that have experienced dramatic

70. Afua Hirsch, Corporate work is the next regulatory hazard, THE GUARDIAN, March 30, 2009, at 15. This article reports on a study commissioned by The Law Society in the UK. Nick Smedley, Review of the Regulation of Corporate Legal Work (March 31, 2009), http://www.lawsociety.org.uk/regulatory-review.page. The Law Society has also commissioned a comprehensive review of the entire solicitor profession under the direction of Lord Hunt of Wirral. The changes in the UK are described at: Legal Services Act - glossary of terms, SOLICITORS REGULATION AUTHORITY (September 29, 2010). http://www.sra.org.uk/sra/legal-services-act/sa-glossary.page. In discussing the move to what is called Alternative Business Structures (ABSs) new types of law firms will be allowed starting in 2011. These include a "firm with more than 25 per cent ownership share held by what are termed non-lawyer managers or a company taken over by a non-lawyer enterprise, or a company floated on the stock exchange, or a firm which provides both solicitor services and non-legal services." Id.; see also, Sir David Clementi, Report of the Review of the Regulatory Framework for Legal Services in England and Wales, NAT'L ARCHIVES (December 2004), http://webarchive.nationalarchives.gov.uk/+/http://www.legal-services-review.org.uk/ content/report/index.htm (archived content maintained by the Ministry of Justice). Further, the Center for the Study of the Legal Profession, at Georgetown University Law Center held a symposium on the changing global nature of the law firm. See, Symposium on the Future of the Global Law Firm, GEORGETOWN.EDU (April 17-18, 2008), http://www.law.george town.edu/legalprofession/GlobalLawFirm.html. The site provides links to papers on the topic. See generally Chandler N. Hodge, Law Firms in the U.S.: To Go Public or Not to Go Public, 34 U. DAYTON L. REV. 79 (2008-2009).

71. Lawyer Demographics, ABA (2008), http://www.abanet.org/marketresearch/ resource.html (last visited May 30, 2009) [hereinafter: ABA Demographics]. 
drops in their real income of nearly fifty percent over twenty years. ${ }^{72}$ This decline is portrayed starkly in the study Chicago Lawyers II that replicated the original Chicago Lawyers study by Heinz and Laumann. ${ }^{73}$ Chicago Lawyers II determined that over a period of only twenty years the income of solo practitioners declined from $\$ 99,000$ to only $\$ 55,000$ in constant 1995 dollars. ${ }^{74}$ From the perspective of quality of life and status an additionally stunning figure was that thirty-two percent of the solo practitioners were working a second job in 1995. This compared with two percent in the original 1975 analysis. $^{75}$

However dismal, it may not be much of a reach to envision a recent law graduate meeting with a client during the day and having the unfortunate experience of serving a cheeseburger to that same person across a McDonald's counter late at night to try to make ends meet. One might be allowed to speculate that this is not the kind of quality of life that applicants to law school envisioned when entering their studies and assuming massive amounts of educational debt.

The growth in the number of lawyers over a thirty year period in the United States has been dramatic. There were, for example, 335,200 lawyers in 1970 at a ratio of 1 lawyer to 606 Americans; 542,000 in 1980 at 1 to $432 ; 725,500$ in 1990 at 1 to 343 ; and approximately $1,000,000$ in 2000 at 1 to $281 .^{76}$ In 2008 , the numbers had increased to $1,162,124$ at 1 to $261 .^{77}$ Even these numbers can be deceiving. Behind the gross data there are additional considerations that include the fact that these are net figures and do not account for the exit of lawyers through death or retirement. They also do not take into account the fact that there has been a compression or skewing of the lawyer base toward more recent graduates, many of whom have more limited job prospects and high debt loads as a result of borrowing to finance their undergraduate and law school education.

There are more than 1.1 million lawyers now licensed to practice in the U.S., including 400,000 or so who have entered the profession just in the past ten years, or nearly forty percent of the entire competitive group in-

72. See generally John P. Heinz, et al., Urban LaWyers: The New Social Structure of the Bar (2005); John P. Heinz \& Edward O. Laumann, Chicago lawyers: THE SOCial Structure OF THE BAR (1982) [hereinafter ChiCago LaWYERS II].

73. CHICAGO LAWYERS II, supra note 72, at 3-9 (explaining the scope and nature of the study).

74. Id. at 163 .

75. Id. at 164 .

76. Id. at 8; see also Population Growth US 1960-2000, CENSUSSCOPE, http://www.censusscope.org/us/chart_popl.html (last visited Jan. 17, 2011). The data place the 1980 population at $226,545,805$, the 1990 population at $248,709,873$ and the 2000 population at $281,421,906$. The 1970 population was $203,302,031$. Id.

77. NATIONAL LAWYER POPULATION, supra note 53. 
volved in private practice. ${ }^{78}$ Fifty percent of the lawyers in private practice are in solo situations with another fifteen percent in very small law firms with two to five lawyers. ${ }^{79}$ At least until recently, the system has been able to absorb the new graduates in enough ways to render the situation relatively invisible from the schools' perspective. This was because enough jobs were available, law firms were able to establish different tiers of temporary contract employment for lawyers that provided some income and reduced the costs of the firms' practice, and alternative forms of employment in business and other fields existed.

In the twenty-year period between 1980 and 2000, there was a 100 percent increase in the number of solo practitioners (an additional 174,606) and another 30,000 or approximately thirty-five percent more lawyers in the two to five lawyer firms. ${ }^{80}$ Given the fact that nearly 400,000 new graduates have entered the legal profession since 2000 , and that the numbers of goodpaying law jobs with stable law firms has been under great pressure, it is reasonable to conclude that the majority of the more recent graduates have gone into solo practices for which they are ill-prepared, formed associated relationships with others similarly situated to spread operating costs, or become vulnerable junior associates in small firms that themselves are operating on the margin.

Although the logic suggests strongly that there are too many lawyers in the United States, the problem is not simply one of absolute numbers. This requires that we understand the internal demographics of the legal profession as well as the gross numbers. These have to do with how lawyers were distributed by function and size of law practice. In 1980, sixty-eight percent of U.S. lawyers were in private practice; in 1991, seventy-three percent; and in 2000 , seventy-four percent. ${ }^{81}$ In 1980 , of a total of 542,000 lawyers 368,560 lawyers were in private practice; by $1991,529,615$; and in $2000,789,082$ out of $1,066,328$ total lawyers. ${ }^{82}$ Of the lawyers in private

78. See data at ENROLLMENT AND DEGREes AWARDED, supra note 30.

79. AM. BAR Ass'N, Lawyer Demographics (2009), available at http://new.abanet .org/marketresearch/PublicDocuments/Lawyer_Demographics.pdf [hereinafter Lawyer Demographics].

80. These numbers are based on the total number of lawyers in 1980 versus 2000 multiplied by the percentage of lawyers in solo practice $49 \%$ in 1980 and $48 \%$ in 2000 , and by $22 \%$ in $2-5$ person firms in 1980 and $15 \%$ in those "micro-firms " in 2000 . The differences do not stem from the percentages themselves but from the growth in the absolute number of lawyers. For example, see Barbara A. Curran, American Lawyers in the 1980s: A Profession in Transition, 20 L. \& Soc. REv. 19-54 (1986). Curran places the U.S. lawyer population at 542,000 at the end of 1980. Id.; see also Lawyer Demographics, id., reports $1,066,328$ lawyers employed in 2000. Applying the percentages in each practice format (2-5 lawyer firms and solo practice) results in 119,240 lawyers in the 2-5 person firms in 1980 versus 159,949 in 2000 , and 265,580 solo practitioners in 1980 versus 518,837 in 2000 . Id.

81. Id.

82. Id. 
practice during those three years of reference, forty-nine percent (1980), forty-five percent (1991), and forty-eight percent (2000) were in solo practice, and twenty-two percent (1980), fifteen percent (1991), and fifteen percent (2000) were in law firms of between two to five lawyers during those periods. ${ }^{83}$ In absolute terms, this means that in each year for which the data are provided, there were 265,580 in solo practice and 119,240 in two to five person firms (1980); and 518,837 solo and 159,949 in two to five lawyer firms in 2000. These data indicate that forty-eight percent of lawyers were "flying solo" and another fifteen percent worked in very small law firms. Sixty-three percent of all private lawyers were in that highly competitive microcosm. ${ }^{84}$

\section{A LoSS OF SYSTEMIC ELASTICITY}

Another element of the reduced relative elasticity of the system's ability to absorb the influx of recent graduates is that for some time new law graduates were able to set up solo or associated law practices with the hope they would be able to "grow" those practices into a significant economic activity. ${ }^{85}$ The reality for many, however, is not that this was a career path of choice but one followed of necessity due to a lack of employment alternatives. This soloing option has become of increasingly limited utility because the large-scale influx of new law graduates relative to paying clients has saturated an already full system relative to supply and demand. ${ }^{86}$ For

83. LAWYER DEMOGRAPHICS, supra note 79.

84. Market Research, ABA, http://new.abanet.org/marketresearch/PublicDocuments /Lawyer_Demographics.pdf (last visited Jan. 17, 2011) (stating that $48 \%$ of U.S. lawyers were in solo practice in 2008 and another $15 \%$ in $2-5$ lawyer firms, resulting in $63 \%$ in those forms of law practice); The Lawyer Statistical Report 1985, 1994 and 2004 editions, ABA, http://new.abanet.org/marketresearchPages/StatisticalResources.aspx (last visited Jan. 17, 2011).

85. One area offered as a possible source of employment is in-house counsel for corporations. The problem is that even that traditional option appears to be contracting at a rate similar to the law firm market. See, e.g., Barbara Rose, In-House is No Haven: As Businesses Shrink Staff, Lawyers are Among Those Being Laid Off, A.B.A. J., June 2009, at 45, 45 ("Logic suggests that when the economy tanks, opportunities for in-house lawyers ought to improve. After all, legal disputes rise when the Dow takes a dive, and who better to tackle this growing workload than cost-efficient staff attorneys? Yet the nation's in-house barhowever vital its role in hard times - is shrinking at a rate that tracks the widening job losses across corporate America. The layoffs are less visible and harder to tally than the widely publicized firings at major law firms, but their impact is no less real. On Wall Street alone, hundreds of lawyers' jobs have disappeared. Some will never come back. By far the hardest-hit sectors are financial services and real estate, but no industry is immune to a downturn that many economists say may be more than a cyclical dip. They suggest the economy is restructuring on a longer-term path of slower growth." (emphasis added)).

86. There are strong indicators of problems in the employment markets for lawyers, with behaviors by firms that run counter to traditional employment trends. See, e.g., Lisa 
most new graduates who end up opening solo law practices it can be expected that they will be experiencing a minimal earnings "dog-eat-dog" competitive climate.

As suggested above, it is not simply a matter of increased numbers of lawyers. There are demographic "bulges" and compressions produced by the rapid expansion of law graduates over a short time period that can be thought of as injecting the system with a high pressure "firehose" of new lawyers. These new entrants were and are being fed into the system in ways that raise its internal competitive pressures and overcome the system's absorptive capacity.

The data indicate that the median age of lawyers increased during the period $1980-2000 .{ }^{87}$ This suggests that there is a substantial bulge of lawyers who entered the legal profession fifteen to twenty years ago, who are in solo and small firm practices, and who are not able to retire from a financial point of view or are too young to do so. It can be expected that many of these lawyers have spent years developing client bases, reputations, and referral networks that allow them to lock up a substantial portion of existing clients who use the services of lawyers working in these tiers of law practice. This means that new lawyers coming into the competitive field find that the resources represented by clients have already been harvested by more experienced practitioners and that the "pickings" are slim. ${ }^{88}$

Fairfax, And Speaking of Job Loss . ., THE Conglomerate (Nov. 13, 2008), http://www.the conglomerate.org/2008/11/and-speaking-of.html. Fairfax comments on the unusual occurrences in the lawyer job market in which layoffs are occurring in a context that historically meant more work for lawyers who were required to help beleaguered clients in an economic downturn. This time, however, the lawyers were being downsized as well. Id. Citing a New York Times article Fairfax indicates the reasons for the differences included:

1. Big company litigation has not materialized, and hence there is no need for law firms to "pit armies of associates against each other."

2. Too many lawyers with the wrong kind of expertise...

3. Increased reliance [by companies] on internal lawyers.

4. Changes in billing practices. That is a movement away from hourly rates and towards negotiating "flat fees, fixed fees, or success fees." Like the lack of big company litigation, the change in billing practices reduces the need for, and/or attractiveness of, armies of associates.

Id. (internal citation omitted).

87. LAWYER DEMOGRAPHICS, supra note 79.

88. See, e.g., Rose, supra note 85 , at $47-48$. The article offers the reaction of a highly experienced corporate counsel who lost her job after 20 years and is seeking legal employment: "I've never seen a marketplace like this before .... It's very bleak. There are weeks I have to stretch to find positions I can even apply for." Id. 
As suggested by Chicago Lawyers II, the conditions of smaller scale and solo practice have deteriorated for many lawyers and have forced unexpected adjustments, even among solo practitioners who have spent some years in law practice. An old friend in solo practice who commented on an earlier draft of this Essay remarked that: "I've always striven to run a solo practice economically and sans support clerical staff. Now, as mentioned in your article, I've 'downscaled' effective this month on tax day to a home law office consisting of a remodeled single car garage that has been nicely but inexpensively tricked out." ${ }^{\prime 89}$

Given the numerical dominance of solo practitioners and small firms competing in the market for legal services (roughly two-thirds of private practitioners), and the fact that established practitioners on those competitive levels predictably have already captured a greater share of that client market, new graduates are foreclosed even from competing with any degree of success on the solo and small firm levels. They are entering a saturated market in which already established competitors have most of the advantages.

Lawyers who are already working on this smaller scale of law practice operating according to reduced economies of scale also have a very limited need or economic ability to hire new law graduates and this further reduces the job market for new graduates. ${ }^{90}$ Many of those established lawyers fill their "gofer" gaps by hiring law students and paralegals at substantially lower pay rates and expectations than would be created by bringing new lawyers into their firm.

Similarly, a substantial number of lawyers with several years of experience in larger firms are finding themselves cut loose by those law firms and make up a pool of experienced competitors vying with inexperienced new graduates for the limited number of available positions. These discarded lawyers with some significant experience and solid paper credentials based on a high level of law school achievements may not have seized the "brass ring" in the cut throat world of the most prestigious law firms but can pose an attractive option for potential clients when setting up solo practices or small boutique law firms.

This suggests at least two conclusions. One is that this significant group of established "middle-age" lawyers in terms of length of time in practice and business development has the ability to control a larger share of that client base compared to the recent graduates who are trying to break into this client market. To appreciate what is occurring on the solo and

89. E-mail from Rod Jones to David Barnhizer (March 31, 2009, 01:48 AM) (on file with author).

90. See G.M. Filisko, Turn-around: Solos Seek Advice to Survive a Struggling Economy, A.B.A. J., Mar. 2010, at 51, $51-55$ (discussing the difficulties faced by those in solo law practice). 
small firm levels of law practice, mean or average figures on earnings, such as the $\$ 55,000$ earnings average found in the Chicago Lawyers II study, are dramatic in their own right. But it is almost certain that the patterns of income distribution that in those domains would demonstrate that a significant proportion of solo practitioners are in a dire state in terms of earnings. This can be understood perhaps by admitting the probability that nearly all the lawyers in large firms have substantial earnings while the solo practitioner data would show a radically different income distribution pattern. Some solo and small firm practitioners would have very high earnings, others respectable earnings, but a very large percentage of solo practitioners would demonstrate quite low earnings.

\section{RESTRUCTURING OF THE TRADITIONAL JOB MARKETS}

In the past year there has been a rapid increase in downsizing by many of the large law firms, including approaches that have seen fired associates, non-equity partners who have been let go from firms, and even the withdrawal or deferral of offers to new law graduates. ${ }^{91}$ Even with these new economic conditions hitting hard in large firm law practices, the situation is bleaker for many lawyers engaged in solo practices, in shared expense arrangements aimed at spreading costs among an otherwise non-affiliated group of lawyers, and in small law firms.

While nearly anyone can pass the bar examination and "hang up a shingle" announcing their willingness to represent clients, increasingly sig-

91. See Baldas, supra note 65; see also Ameet Sachdev, Big Firms Cut Back on Law School Recruiting, CHI. TRIB. (Sept. 1, 2009), http://archives.chicagotribune.com 12009/sep/01/business/chi-biz-law-firms-cut-recruiting-sep01. Sachdev reports:

Seyfarth Shaw canceled its 2010 summer program. Skadden Arps Slate Meagher $\&$ Flom, which has a large Chicago presence, has said it expects to hire nationally about 100 interns-also known as summer associates-next year, down from 225 in this year's summer class.

The [University of Illinois] College of Law expects [only] about 60 firms . . this year [to conduct] on-campus interviews, down from a peak of more than 100 just two years ago.

[The decrease reflects the fact that] firms are re-evaluating their hiring model because the demand for legal work is depressed, and they can't forecast when it will recover. Firms [have] responded by laying off associates, cutting salaries and Id. postponing the start dates of the 2009 class of law-school graduates until next year. 
nificant entry barriers have been erected that prevent that strategy from being effective. At the solo practice level of doing a law business the issue becomes one of almost no entry barriers to setting up a law practice other than passing a bar examination in the relevant jurisdiction. Once past the solo practice level, however, increasingly significant barriers come into play to the point that perhaps one in fifty or one hundred new law graduates have access to the employment market represented by large or medium sized firms.

This suggests that to the extent there is an oversupply of lawyers, many of the new graduates end up taking the only path in private practice open to them-"flying solo." The competition for clients has intensified within the solo and small firm context overall as the ranks have grown rapidly due to the combination of the large number of new lawyers and the significant pool of existing lawyers who are "stuck" in their law practices.

For such lawyers the personal costs of living and the expenses of law practice are essentially inseparable. The total debt burden and operating costs involved in practicing law and paying for already incurred personal, educational, and professional expenses is a continual burden that must be met-whether viewed as capital expenditures or day-to-day costs. Substantial expenses and debt burdens are associated with pre-existing expenses incurred in the process of gaining a law degree, the capital and operating costs of setting up a practice, and the expenses and earnings expectations of lawyers and their families. Many of the solo practitioners are brand new or at least relatively new to the legal profession and are forced to compete with more experienced and established lawyers for a limited client base of clients capable and willing to pay fees for legal services.

This combination creates an economic burden that many lawyers cannot overcome on a consistent basis. It is a deadly cycle where, as the costs of obtaining a law degree increased dramatically, the earnings of many solo practitioners fell just as dramatically. As suggested above, many recent law graduates enter solo and smaller law practices either because they lack access to the law firms who pay the "big bucks," or are unwilling to accept the demands of such firms. It is a significant problem that the intensity of competition for paying clients on this micro-level of law practice (solo, associations for expense sharing, and up to five lawyer firms) has increased dramatically, even as lawyers operating on this scale of practice have substantial debt loads and reduced average earnings.

The effects of the oversupply of lawyers differ by scale of practice and, presumably, by type of practice and the extent to which the lawyer has gained competitively beneficial relationships, networks, and a positive reputation of the kind that could lead to client word-of-mouth referrals. Research examining Indiana lawyers over a five-year period suggests the diffe- 
rential effects as well as the distinction in income gain or loss associated with scale of practice. ${ }^{92}$ These data demonstrate that the category of solo practitioner and the two to five lawyer firms which together make up twothirds of private practitioners are particularly hard hit.

The same data show loss in real income terms far less at the large firm level with 20.2 percent of lawyers at the solo practice level experiencing real declines in income but only 3.8 percent of lawyers in the large firms experiencing declines. ${ }^{93}$ At those levels, thirty-seven percent of solo practitioners saw their earnings stagnate in real terms, while only seventeen percent of large firm lawyers reported nominal increases in earnings, and seventy-seven percent of large firm lawyers reported real increases in income for the period. ${ }^{94}$ At the two-to-five lawyer firm size, seventeen percent experienced declines in earnings, with thirty-seven percent only nominal earnings increases in real dollars. ${ }^{95}$

It is likely that there are differential effects relating to the relative impact of the declines. A loss in earnings of $\$ 10,000-20,000$ may spell disaster for solo practitioners already operating at the margins. Loss in earnings of $\$ 10,000-20,000$ at the higher earnings level may represent only five percent of annual earnings and might even be uncomfortable due to more expensive life style choices but it is marginal money to which adjustments can be made. That same amount at the solo level can mean the difference between survival and bankruptcy. Similarly, nominal and static earnings or earnings declines do not take into account the full costs of increased health care, employment taxes, energy costs, commercial rent, and many other services necessary and unique to the business of law practice.

The scale of the money at stake is significant for a lawyer operating as part of one of the large law firms represented by The American Lawyer's AMLAW 100 and 200. Partners at AMLAW's 100 largest U.S. firms made an average profit of $\$ 1,315,000$. Some law firms exceeded $\$ 3,000,000$ in individual partner profits. In 2007, the average per-partner profit at a U.S. law firm ranked by The American Lawyer as being "relegated" to the Second Hundred largest firm category represented by gross annual revenues was $\$ 666,000 .^{96}$ The "carrot" of achieving such incomes is highly seduc-

92. See William D. Henderson, Professor of Law, Indiana Univ. Sch. of LawBloomington, Financial and Billing Survey of ISBA Lawyers, Address at the 2007 Solo \& Small Firm Conference (May 31-June 2, 2007), available at http://www.law.indiana.edu/people/henderson/share/ISBA.pdf; The Law School Investment, WALL ST. J., http://online.wsj.com/public/resources/documents/info-Law0709-24.html (last visited Jan. 8, 2011).

93. Id.

94. Id.

95. Id.

96. Aric Press \& John O'Connor, The American Lawyer, LAw.com (May 30, 2008), http://www.law.com/jsp/article.jsp?id=1202421806313. They report: "The average Second 
tive and the "stick" of failing to maintain or even losing this level of income is sufficient to generate the behaviors necessary to preserve the continued largesse. ${ }^{97}$ This can have a serious corrosive effect on the professionalism and integrity of the lawyers fighting to generate the revenue streams that provide the earnings and benefits to which they feel entitled and on which they have become dependent.

Salaries in excess of $\$ 200,000$ for associates with only a few years experience provide the firms with an unceasing supply of replacements as those who enter the gauntlet after law school and a prestigious judicial clerkship are used up by the firms and then mostly relegated to permanent associate status after four years or told that it might be a good idea to quietly seek other employment. During their time in competition for the brass ring, the contestants may have been told that the firm's expectations were that they work 1,800 to 2,000 billable hours per year but the reality is that the competition demands that the associate "show the flag" and out-compete others vying for the promotion. This is done by working twelve-hour days, six days per week and not infrequently showing up on Sunday. Annual billings per associate of 2,200 and 2,400 billable hours are not uncommon. ${ }^{98}$ To achieve this output the actual time spent at work can add up to as high as 2,800 to 3,000 hours per year since not all hours can be billed. ${ }^{99}$

Hundred firm has 289 lawyers, 92 equity partners, gross revenue of $\$ 170$ million, revenue per lawyer of about $\$ 589,000$, and profits per partner of $\$ 666,000$." Id.

97. Id. Press and O'Connor anticipate an even more dramatic drop in large firm earnings of a kind that is likely to accelerate their downsizing and reduce new hiring. Id. They report that we are seeing only the beginning of a dismal period for the firms:

To test that theory, we ran a couple of simple calculations. Many observers predict a 10 percent drop in gross revenues in 2009. If that's true, and all lawyer head counts were to remain flat, PPP in 2009 would fall by about $\$ 360,000$, to $\$ 925,000$. Alternatively, if you assume a 10 percent drop in gross, you can hold PPP steady, on average, by cutting a little more than 10 percent of the lawyers, 84 out of the average-size firm of 820 . The cuts don't have to be confined to a single category: lopping off 66 associates and 18 equity partners will hold the line for the survivors.

Id. They add: "There will be blood -2008 was not the bottom, just the beginning." Id.

98. For data on some large law firms see an outline provided by the law school at the University of Nevada, Las Vegas, Keeping an Eye on the Clock: The Truth about Billable Hours (on file with author) [hereinafter UNLV Compilation]. The analysis in this outline covers reports from Nevada law firms for 2007 and estimates that twenty-five percent of the ten hours per day worked by an associate would not be billable to clients. Id.

99. The UNLV compilation, supra note 98 , appears understated. The Avery Index (AI) offers significantly differing data on hours worked by large law firm associates, based on its 2006 Midlevel Associates Survey. The Al's analysis of the firms with the longest and shortest hours worked is found at http://www.averyindex.com/longest_hours.php (last visited Jan. 17, 2011). It reports that "Associates at the \#1 firm, Carter Ledyard \& Milburn, averaged 50 hours worked ( 39.3 billed) per week. Associates working the longest are at, Wachtell, Lipton, Rosen \& Katz, and worked on average 69.1 (and billed 59.6) hours per week." 
VIII. THE PENDING SHIFT TO "OUTCOME" ASSESSMENTS IN ABA LAW SCHOOL ACCREDITATION STANDARDS AND THE POTENTIAL IMPACT ON

\section{LAW SCHOOLS}

Several potential shifts in $A B A$ accreditation standards and policy are likely to have significant implications far beyond their surface appearance. These shifts include approval of credit for distance learning, and rapid movement of the ABA accreditation process toward assessment of law schools based on what are called "output" measurements rather than the capital and budgetary "input" measures that have previously dominated the process.

Of equal significance is a decision that scholarly productivity measures are an inappropriate factor for the ABA (contrasted with the AALS) to include when assessing the accredited status of a law school. These three accreditation prongs-distance learning, output assessment, and elimination of requirements for scholarly productivity - may seem relatively inconsequential. But individually and collectively they will have enormous effects even to the point of significant faculty reductions, higher faculty workloads, changes in tenure standards, and large-scale eliminations of the traditional law school research library. ${ }^{100}$

Distance learning, for example, could offer the option of several law schools sharing a single faculty member to teach a section of the same course from a remote location with the classes scheduled at the same time. A cost-effective approach could involve three or five or ten law schools teaching large lecture courses simultaneously by video broadcasts backed up by teaching assistants and interactive computer programs. One colleague, in commenting on this draft in connection with the utility of distance learning, observed:

As to distance learning, I used to think it was a bunch of hooey until a couple of years ago when a dear friend enrolled on a program to finish her bachelor's degree (she already had an associate's degree in nursing from Ursuline College here in the ... [Cleveland] area). It was a very rigorous academic experience with a lot of "real time" interaction with the other students and the prof, major research and writing assignments, and other traditional educational exercises. I don't know

Id. Assuming a Wachtell Lipton associate receives three weeks vacation per year he or she would be working 3386 hours per year and billing 2920 . The associate at Carter Ledyard is working 2450 hours annually based on these assumptions and billing 1926 hours. Id.

100. See Steven R. Smith, Gresham's Law in Legal Education, 17 J. CONTEMP. LEGAL ISSUES 171, 205-06 (2008) for an excellent analysis of some of the key accreditation issues. Dean Smith is extremely knowledgeable in regard to accreditation issues and has been immersed in both the ABA and AALS accreditation processes for several decades. 
which school offered it but I would say that overall it was an excellent academic program. $^{101}$

Output measurement could take a variety of forms. Measuring the acceptability of a law school's program for accreditation purposes by measuring output almost certainly means placing primary emphasis on whether the institution's graduates are able to pass a bar examination given that it is virtually impossible (at this time) to point to any other measurement standard. ${ }^{102}$ The problem with relying primarily or solely on bar passage is that it is likely that, once pressured to demonstrate its validity as a job-related measurement tool, the classic form of the bar examination will not be able to offer adequate empirical proof of its utility. That process may therefore be forced to adapt dramatically or even give way to other measurement tools yet to be developed.

Even here, however, the "skeleton in the closet" is that we shouldn't leap too quickly to the conclusion that no other effective test exists. One measurement tool could be as simple as successful completion of the law school curriculum, particularly given the fact that the bar exam undeniably tests the same analytical skills and base of knowledge that is then "retested" by the bar examination. If we ignore the tradition of individual state bar exams that at this point serve primarily as anti-competitive entry barriers that protect the economic interests of the lawyers of a particular state, it seems far more appropriate to rely on a recent law graduate's entire body of work in law school. This is arguably better represented by successful completion of a three or four year law curriculum largely mandated by the ABA than on a two or three day "all-or-nothing" hazing ritual of the kind provided by the bar exam.

\section{DEFINING THE ABA's LEGITIMATE Role IN ACCREDITATION IN THE CONTEXT OF SCHOLARLY PRODUCTIVITY}

Removing the scholarly productivity measure from the ABA standards, as has been reluctantly suggested by long-time ABA and AALS accreditation insider Steven R. Smith, Dean of California Western School of Law and former Chair of the ABA's accreditation committee, means not only the elimination of the standard for many law schools but it opens the door for new law schools that possess no concern for publication but concentrate entirely on the educational process. ${ }^{103}$ This creates the likelihood

101. Email from Susan Becker, Professor of Law, Cleveland-Marshall College of Law, to David Barnhizer (Nov. 1, 2009, 20:20:41 EST) (on file with author).

102. Smith, supra note 100 , at 195-96.

103. Smith, supra note 100, at 205-06; see also Karen Sloan, Law Faculty Upset Over ABA's Proposed Tenure Shift, NAT'L L.J., (July 27, 2010), available at http://www.law.com/jsp/article.jsp?id=1202463917764. Sloan notes: 
that faculty would be expected to carry significantly higher teaching loads. It also would mean there would be no necessity to supply, maintain, and staff large scale and expensive research libraries of the kind now found in most law schools. Of course, law schools such as Harvard would continue largely unchanged, but those on the grinding competitive margins will be significantly affected.

Once the competitive and accreditation environment in which law schools operate is transformed, the effects will strike with full force at the margins occupied by as many as a third of American law schools. This will result in a paradigm shift in the nature of American legal education, one that a few law schools appear to be anticipating by adaptations in size and curricular developments but that most law schools will ignore. ${ }^{104}$ For the many law schools that choose to remain oblivious to the altered operational context, their adaptations will be ones developed in a crisis context. Decisions will be made as their applicant pools shrink, graduates are unable to find employment while faced with educational debt equivalent to a home mortgage, and less expensive competitive institutions emerge that offer alternative approaches to legal education.

The ABA subcommittee examining job security and academic freedom has concluded that the existing standards don't require law schools to maintain a tenure system in the first place, despite interpretations to the contrary. The standards say that "a law school shall have a comprehensive system for evaluating candidates for promotion and tenure or other forms of security of position. . . .

The proposed standards would clarify that law schools are not obligated to offer Id. tenure but make clear that schools must protect academic freedom . . . .

104. See Elie Mystal, Obsession With Tenure and Money Likely to Ruin the Future of Legal Education, ABOVE THE LAW (Apr. 15, 2010, 6:53 PM), http://abovethelaw.com/2010/04/obsession-with-tenure-and-money-likely-to-ruin-the-futureof-legal-education/, for a description of the predictable response espoused/presented at the joint Harvard/New York Law School conference on the future of legal education held in the Spring of 2010. Mystal observes: "[A]ssembled law school deans, professors, and other educators spent a lot of time talking about the past. ... The future, it seems, is in a holding pattern until law school professors can figure out how to get tenure under alternative models of legal education." Id. In describing the audience reactions to reform proposals, Mystal adds that the professors' questions focused on: "Can you get tenure doing this? Will you be up for tenure more quickly doing that? Will tenure requirements be softened for professors that teach over the summer? How do I get tenure?" Id. Mystal observed:

Have you ever seen a pack of hyenas wrench a meal from a leopard? That's what the Q\&A reminded me of. The panel was trying to keep the focus on educational opportunities for students, but the audience just wouldn't let them stay on point. Instead, we got waves and waves of tenure questions.

Id. 
For the purposes of this analysis, claims about the relative educational quality of legal education across the range of law schools are irrelevant. This is because, from the perspective of curriculum and qualified and competent teaching faculty, there is not much of a real distinction among law schools. This fact has significance once the system is examined at arm's length rather than with the blinders of bias and tradition.

But even if the internal substantive quality and method of legal education are essentially identical across the range of law schools, the obvious and primary differences between law schools are in prestige, academic research productivity, or at least the system's perception of productivity, and the employment niches and territorial sweep of job placement of law graduates by different law schools.

Educational costs are also important factors for competitive placement among the schools. But from the perspective of curriculum content and structure, materials covered in classes and tested on examinations, and the teaching ability of the faculty, American law schools are a homogenous set of institutions regardless of what the rigid hierarchy and "pecking order" of law school rankings suggest.

The differences between American law schools are not primarily ones of substance and intellectual prowess but of prestige and snobbery, access to "Old Boy and Girl" employment networks that favor graduates of particular institutions and tend to strongly disfavor the products of "lesser" law schools, and access to different areas and types of practice. But what the law schools themselves offer students from an educational perspective is a virtually indistinguishable experience in terms of the material studied, methods of instruction, and generic quality of teacher. If there are internal educational differences, they are more likely ones produced by the challenge and the intensity of interaction with a student culture comprised of a greater proportion of intellectually gifted and driven students than by the law faculty. ${ }^{105}$

105. For insight on this issue of "intellectually gifted," see E-mail from Joan Howarth, supra note 50 ("Yes, I agree about faculties, at least regarding the students' experience, and I mainly agree about the student body differences. The meaning of 'intellectually gifted' could be scrutinized here. I know for sure that the students I had at Boalt were more successful students than the students I had at Golden Gate, but many of the GGU students were "intellectually gifted," but less successful students for a wide variety of reasons, including English as a second language, lack of work ethic, personality issues, family responsibilities, etc., etc. In my experience, you were as likely to encounter student brilliance at GGU, but it was more likely to be paired with something very negative related to academic success, ranging from cultural issues to passion for playing jazz in the middle of the night to heroin addiction to a deeply anti-authority attitude .... I think it's hard to overestimate the importance of class in determining prowess as a student."). 


\section{DESCRIPTION OF A POSSIBLE "UNIVERSITY OF PHOENIX" OR KAPLAN UNIVERSITY LAW SCHOOL SYSTEM}

The best way to illustrate what could occur is to invent new models of law schools such as could easily occur with the national expansion of the University of Phoenix. Phoenix has experienced a rapid and stunning success, and offers a distinct model of a sort of disconnected neo-university education. The Phoenix Model is more flexible, fluid, requires less investment capital, and reduces labor and operating costs. As it aggressively spread across the U.S. in a decade, the "University of Phoenix" approach represented a change in educational psychology, use of technology, promotion to specific market niches, budgeting, hiring, and method. The new model is an example of one powerful approach that is capable of supplanting a substantial part of traditional legal education.

The Phoenix Model also makes it far easier and probable that competitive alternatives will rapidly emerge that will challenge some law schools for applicants. It can also offer the equivalent of lower cost "law community colleges" from which successful graduates transfer to the upper levels of the traditional law school or receive specialized degrees that allow them to practice a distinct form of technical law. In either mode, there will be a significant impact on the financial and staffing dimensions of the current form of the university-based law school.

Law schools have been almost entirely insulated from this emergent educational model, but there is no reason to expect that state of affairs to continue. Seemingly minor adaptations by the ABA of the kind mentioned above, such as elimination of the prohibition of distance learning accreditation and a shift to measurement of institutional "output" rather than "input" (read ability to pass the bar exam), are far more important than may be realized. The ABA's accreditation system is under pressure to justify itself and the simple fact is that put to the test, many of its requirements are unlikely to withstand even moderate scrutiny. The Concord Law School, owned by Kaplan, is an on-line law school whose graduates have been increasingly having success on the difficult California bar examination.

In a sense, the California system of permitting non-ABA accredited law school graduates to take that state's bar has offered a laboratory for this experiment. ${ }^{106}$ As the ABA shifts to an "outcome" based accreditation

106. Concord's first graduating class of 10 students sat for the California Bar Exam in February 2003 and 6 students passed. This first-time pass rate of 60 percent was more than 2.5 times the first-time pass rate of State Bar-accredited schools (22.4 percent) and also exceeded the performance level of American Bar Association (ABA) accredited law schools based in California ( 57.4 percent), the overall first-time passage rate in the state on that examination (50.2 percent), and the rate for ABA schools located outside of California (48.6 percent). Passing the California Bar Examination, CONCORD LAw SCHOOL, 
model it is incomprehensible that states can continue to deny the opportunity to practice law to graduates who: (1) passed the bar exam, (2) are employed, and (3) have significantly lower educational debt than their counterparts who attended traditional law schools. In this vein, it is hard to understand how the currently non-ABA accredited law schools in California and elsewhere can be denied the chance to place their graduates (and attract online students) from across the U.S. Once the shift is made to outcomes and distance learning for at least a significant part of the educational process, current accreditation factors such as expensive physical facilities, studentfaculty ratios, library volumes, faculty scholarship, and so forth become of much less importance and in some ways largely irrelevant.

The problem is that the existing model of American university legal education is unsustainable. It has gone past any rational peak of maximum price of its product. This will generate alternative models of legal education that will begin to siphon off resources in ways that will make it difficult for many law schools and impossible for some to continue to operate according to existing norms. ${ }^{107}$ The costs of the institution of the traditional university-based law school and the relatively light workloads of law faculty have reached a point where students and applicants will increasingly seek alternatives. ${ }^{108}$ The dominant reason the law schools have been able to maintain the existing model is a combination of a positive economy and expanding employment opportunities.

The fact that California, with more than forty law schools, already operates under rules that are distinct from the $\mathrm{ABA}$ 's and that graduates of the

http://info.concordlawschool.edu/Pages/Bar_Exam.aspx (last visited Nov. 3, 2010) [hereinafter Passing the California Bar].

107. For an intriguing discussion of the impacts see Karen Sloan, At Public Law Schools, Tuition Jumps Sharply, NAT'L L.J., Aug. 3, 2009, available at http://www.law.com/jsp/nlj/PubArticlePrinterFriendlyNLJ.jsp?id=1202432679213. Students may pay as much as $20 \%$ more at some state institutions. Id. Sloan notes: "The recession is having a 'much more pervasive effect' on law school budgets than did past recessions, said Susan Westerberg Prager, executive director of the Association of American Law Schools (AALS). Specifically, it's hitting hardest at law schools dependent on state appropriations or revenue from endowments." Id.

108. Id. Sloan offers examples of tuition increases that include:

In-state students at Indiana University Maurer School of Law-Bloomington will pay almost $25 \%$ more in tuition than they paid last year, bringing their tuition from just below $\$ 20,000$ to nearly $\$ 25,000$. Iowa residents will see tuition increase by nearly $20 \%$ next year at the University of Iowa College of Law, while out-of-state students will pay an additional $13 \%$. Tuition at the University of Colorado School of Law is increasing by $16 \%, 20 \%$ and $12 \%$ for in-state $1 \mathrm{Ls}, 2 \mathrm{Ls}$ and $3 \mathrm{Ls}$, respectively. Resident students at the University of Texas School of Law will pay $16 \%$ more and nonresidents will see tuition go up by nearly $11 \%$. Tuition is up $15 \%$ for in-state $1 \mathrm{Ls}$ at the University of Minnesota Law School, while in-state $2 \mathrm{Ls}$, 3Ls and out-of state students will see increases of nearly $8 \%$.

Id. 
non-ABA accredited law schools in California nonetheless pass the difficult California bar exam and acquire the right to practice law in that state representing twelve percent of the U.S. population offers a clear "output" gauge that is difficult to deny. ${ }^{109}$

If law school is considered as an institution with the main purpose of educating people to become lawyers as suggested by Steven Smith's analysis of why the ABA should not be in the business of including faculty research productivity in its standards, ${ }^{110}$ and if the bar exam is justified as the instrument by which the success of that effort is measured, then bar passage is the primary and possibly even the sole measure of educational quality by which we are to be judged. When this premise is accepted, much of the accreditation authority of the ABA is automatically reduced because everything else is unrelated to the only empirical standard by which the quality of law graduates or other aspirants to law practice can be properly judged-bar examination passage as demonstration of the knowledge and analytical skill necessary to engage in the effective practice of law.

The Phoenix Model offers an alternative educational approach, and using the concept to describe a variation and a challenge for traditional law schools may help us focus. For the alternative model to provide a significant challenge to the traditional model, several changes in the rules of operation are essential. They include the following:

109. California dominates the non-ABA accredited law schools in the U.S. with at least 30 institutions. Choosing a Law School, LSAC.ORG, http://www.lsac.org/jd/Choose/l aw-school-links.asp (last visited Nov. 3, 2010). These include: Abraham Lincoln Law School; American College of Law; CAL Northem School of Law; University of California Irvine School of the Law; California Midland School of Law; California School of Law; California Southern Law School; California Southern University; Concord Law School of Kaplan University; Empire College School of Law; Glendale University College of Law; Humphreys College School of Law; Irvine University College of Law; John F. Kennedy University School of Law; Lincoln Law School of Sacramento; Lincoln Law School of San Jose; Monterey College of Law; University of Northern California-Lorenzo Patino School of Law; Oak Brook College of Law; Pacific Coast University School of Law; Pacific West College of Law; San Francisco Law School; San Joaquin College of Law; Santa Barbara College of Law; Southern California Institute of Law; Taft Law School; Trinity Law School; Ventura College of Law; The University of West Los Angeles School of Law-West Los Angeles; Western Sierra Law School. Id. There are at least another eight non-ABA accredited law schools outside California as well as ten proposed law schools. Id. Once the ABA accreditation system shifts to allow greater distance learning options, no longer requires faculty scholarship or library volumes as important criteria for accreditation, and bases accreditation on "output" measurements relating to bar passage, employment and educational debt loads there is no longer any realistic legal justification for at least a number of these law schools not to be allowed to "go national." Kaplan's Concord Law School is obviously an early leader in this effort but the walls are likely to collapse quickly once the rules change occur.

110. See Smith, supra note 100. 
1. Distance-learning courses must be approved by the accrediting institution so that on-line courses allow successful takers to qualify to take bar exams for admission to law practice. As noted, the ABA is reconsidering its prohibition on on-line courses in $2010 .^{111}$ The State of California Bar allows distance learning already and graduates from Concord Law School in California are passing the California bar exam at a significantly higher rate than graduates from other unaccredited or state-accredited law schools. ${ }^{12}$

2. Given the rapid movement in the general university world toward significantly greater reliance on distance learning in their course offerings, the ABA will find it very difficult to resist this trend. It should be expected that the ABA will move to increasingly allow law study in at least some substantial parts of the law curriculum to be completed by on-line methodologies. An important result from the perspective of current members of law faculties is that the educational strategies allowed by distance learning will reduce the number of full-time law faculty, possibly dramatically. This will also reduce the capital costs of creating and operating a law school, and increase the probability of consolidations and mergers among traditional law schools.

3. Another effect will be the rapid emergence of additional corporate networks of law schools such as InfiLaw (Phoenix Law School, Charleston and Florida Coastal). ${ }^{113}$ Even these fledgling, corporate-owned law schools may find themselves under pressure in the next five to ten years as traditional accreditation barriers fall and alternative on-line and distance learning systems emerge in forms we can't yet anticipate.

4. It is even possible that publicly-funded and private university law schools that find themselves under great financial pressure will resort to the oft-dreaded "public-private" partnership arrangements in which they sell their law schools to corporations to operate for

111. See Neil, supra note 17; GeTEDUCATED.COM, supra note 17.

112. Passing the California Bar, supra note 106.

113. See INFILAw SYSTEM, http://www.infilaw.com/ (last visited Jan. 17, 201 1). The InfiLaw website provides the following description of the system:

The InfiLaw System is a consortium of independent, community based law schools that is establishing itself as a leader in making legal education more responsive to the realities of new career dynamics. The InfiLaw System includes Florida Coastal School of Law in Jacksonville, FL, Phoenix School of Law in Phoenix, AZ and its newest school, Charlotte School of Law in Charlotte, NC which opened in 2006. Its mission is to establish student-centered, ABA accredited law schools in underserved markets that graduate students with the skills of a second-year associate and achieve true diversity programs aimed at student academic and career success. 
profit or enter management contracts with private companies to run existing law schools.

Offering at least fifty percent of a law school's courses on-line would have dramatic effects. One is that the same basic lectures can be repeated with some supplementation for several years. Another is that a single faculty member could "virtually" teach at multiple law schools. This means that rather than only reducing the number of faculty needed to teach at a single law school, the distance learning approach would theoretically allow an unlimited number of schools to teach Torts, Contracts, Corporations, Business Associations, Criminal Law and so on by sharing the on-line lectures of the most consensually-brilliant law faculty in the country.

Once distance learning is approved as an accredited educational device for law schools, the economics of legal education will change dramatically. Not only could law students in fifty different law schools be taught from an identical text, but they could all be taught by the creators of those texts who presumably are masters of that particular substantive universe, highly experienced, and leaders in their field. It is not impossible to contemplate law schools with faculties of five or ten who are retained for necessary esoteric courses and ones that require direct contact such as law clinics, trial advocacy, and similar courses.

In such a model, feedback interactions between faculty and students might actually be enhanced rather than impeded because methods can easily be put in place with online tutorials and a low cost cadre of advanced students or recent graduates who are paid relatively low rates to supply the interactive element when students have questions. The immense costs of traditional law libraries, including materials acquisition and maintenance as well as staffing will fall before the range of information technologies that are now available.

While I absolutely love books and libraries, most modern students are entirely comfortable with web-based information acquisition, and this renders the traditional "hard copy" systems increasingly less important and vulnerable to cost cutting when budgets are under pressure. The traditional library may soon find itself in the same position as steel mills in America where far lower cost competitors rapidly gained competitive advantage and drove U.S. mills out of business. In that context, it is not surprising that the ABA has stated that it was beginning to look toward "outputs" rather than "inputs" in assessing the viability and quality of a law school for accreditation purposes.

Once the ABA's archaic accreditation stranglehold based on anticompetitive conditions, market barriers, and outmoded assumptions about university-based legal education is reduced or eliminated, then radical new options come into play. Assume, hypothetically, that there are three university-based law schools within a thirty-five mile radius in an area of the U.S. 
that has a declining population and economic base and that there are increasing difficulties in finding law jobs faced by many of the graduates of those three hypothetical law schools. Also assume that the three schools enroll a total of approximately 1,925 students, and that Law School \#1 has 525 students, thirty full-time faculty members, six senior administrators, and twenty-eight part-time faculty members. Law School \# 2 has 700 students, forty full-time faculty, twelve senior administrators, and an average of forty-five part-time faculty members. Law School \# 3 has 700 students, forty full-time faculty members, six senior administrators, and thirty-five part-time faculty members. Assume also that the admissions criteria of the three law schools are essentially identical at this point.

The irony is that, viewed entirely from an economic perspective, this means there are three manufacturing companies within the same competitive territory, each of which bears the entire fixed costs of a competitive enterprise at a maximized level and none of which has sought to create the kinds of efficiencies and economies of scale that would reduce the cost of their product. Yet there are very significant scale efficiencies and operational method savings that can easily be identified in what could be the emerging model of legal education.

Begin with the idea that the three hypothetical law schools offer a virtually identical curriculum, apply the same teaching methodologies, manage essentially identical library collections, and basically have faculties and administrators who do the same work. What if a management firm in the business of operating law schools submitted a proposal to the Boards of Trustees of Law Schools 1, 2, and 3 to reduce their costs of operating their university's law school by at least fifty percent. The proposal would be to consolidate most of the administrative activity into one central admissions unit, merge the library systems, include distance learning for roughly sixty percent of the courses, eliminate some esoteric seminars that exist solely for faculty, increase the use of adjuncts and law school teaching assistants, and concentrate scarce resources on courses that were necessarily interactive.

If the cost of operating each law school as an entirely separate system were looked at, we would see something like $\$ 11$ million per year for Law School \#1, \$13 million for Law School \#2, and \$12 million for Law School \#3. This represents $\$ 36$ million per year to provide legal education for 1,900 students, a per student cost of $\$ 18,947$. This involves 110 full-time faculty; twenty-four administrators; 108 part-time faculty members; and perhaps something like 100 other staff (receptionists, secretaries and so forth).

Assumptions:

- Full-Time Faculty salaries (including fringes of $32 \%$ ) at $\$ 165,000$ per year for 110 faculty members. $\$ 18,150,000$

- Senior Administrator salaries (including fringes) at $\$ 200,000$ per year for twenty-four administrators. $\$ 4,800,000$ 
- Part-time salaries for 108 adjunct faculty at $\$ 6000$ per year per adjunct. $\$ 648,000$

- General staffing costs (including fringes) at $\$ 40,000$ per year times 100 staff members. $\$ 4,000,000$

- Library costs for materials, subscriptions and staffing: $\$ 12,000,000$

- Other costs: facility, utilities, security, university support requirements, hardware and upkeep. $\$ 10,000,000$

- Total combined operating costs of Law Schools 1, 2 and 3: $\$ 49,600,000$ [rounded to $\$ 50,000,000$ ].

For the two law schools in our hypothetical that are publicly-funded (Law Schools 1 and 3) with 1,225 law students, we can assume that seventy percent of their students are in-state residents and that twenty-five percent of that number are enrolled part-time. This means that 857 are in-state residents and of that number 214 are part-time students and 643 are full-time students. Assume further that the average tuition of students at Law Schools 1 and 3 is $\$ 18,000$ for full-time state residents, $\$ 12,000$ for parttime students who are state residents and $\$ 28,000$ for non-residents. This means that tuition revenues for Law Schools 1 and 3 are $\$ 11,574,000$ for full-time residents, $\$ 2,568,000$ for resident part-time students, and $\$ 10,304,000$ for 368 out-of-state students. For Law Schools 1 and 3, there are also state subsidies per in-state student of approximately $\$ 5,000$ per year or $\$ 4,285,000$. The two schools provide $\$ 3,500,000$ in grants and scholarships. Law School \#2 is a private university law school with 700 students and tuition of approximately $\$ 40,000$ per year. This results in revenues of approximately $\$ 28,000,000$ per year. Scholarships and grants at Law School 2 total about $\$ 3,410,000$.

Total Revenues for Law Schools 1, 2 and 3: $\$ 54,163,000$

\section{ECONOMIES OF SCALE ProducED by AN ALTERNATIVE MOdEL}

The above figures suggest strongly that dramatic results can be produced by any number of alternative approaches, including greater reliance on distance learning, a management consortium that shares staffing, teaching and administrative resources, as well as library costs and materials. Sharing faculty, library, administrative staff, etc. could reduce the requirements of full-time law faculty by something in the vicinity of fifty percent. With the distance learning option and elimination of redundancies it would be possible to reduce faculty size to fifty full-time law faculty shared among the three institutions. Similarly, administrative overlap could produce savings of another fifty percent, and library reductions of perhaps $\$ 5$ to $\$ 6$ million per year. Part-time costs might even increase.

At fifty full-time faculty members, that cost would be reduced to $\$ 8,250,000$ per year, a savings of $\$ 10$ million. Senior administrative sala- 
ries would fall to $\$ 2.4$ million, and with the $\$ 5$ to $\$ 6$ million in lower library expenses the operating cost of the management approach could save $\$ 17$ to $\$ 18$ million per year. A management fee of $\$ 3$ million would still produce $\$ 15$ million per year in savings. Presumably, this would be attractive to host universities and state legislators and administrators. It could also produce significantly lower tuition costs for students and this would likely make the tripartite consortium more competitive.

I am not saying such actions are inevitable, but I am certainly suggesting that they could occur and that if they do the momentum the new competitive approaches create will be intense and even irresistible for many law schools. The economic pressures are real. Arnold Schwarzenegger, for example, recently sought to take $\$ 10$ million, the entire state subsidy, from the law school budget of the University of Hastings. It was ultimately reduced, but it is a serious "first shot" across the bow for state-supported law schools. ${ }^{114}$

Harvard Law School stated it was reducing its budget ten percent for this year. ${ }^{115}$ Many law school faculties have seen salaries frozen or only token raises. The simple fact is that the job of a university law professor is an incredible privilege, and we have come to take that privilege for granted. The perks of the position have been fantastic and will remain so for many law faculty members. But the "golden age" is ending for many others and they will discover that the "shot across the bow" actually hit below the waterline and they are sinking. The competition and financial pressures will only increase. Business as usual is something in the past, and, unless law schools adapt, many law faculty members will find themselves out of their jobs at very unpleasant moments in their careers.

\section{Possible Competitive Solutions DePending on the NATURE OF THE SPECIFIC LAW SCHOOL}

At this concluding point, I simply want to set out some of the strategic variables that can be adjusted in order to buffer or overcome the most serious effects of the changes we are experiencing. I am not attempting to determine a single choice or set of choices that could be most effective because the specific conditions vary depending on the particular law school, applicant, and employment markets to which the school has access. Factors such as reputational and programmatic realities and opportunities, sources

114. See Cheryl Miller, Budget Ax May Fall on Hastings Law School, THE RECORDER, May 28, 2009 available at LAW.COM, http://www.law.com (last visited Jan. 17, 2011). The proposed cuts were $\$ 10.3$ million. $I d$.

115. Elias J. Groll, Law School Will Cut Staff to Trim Budget, Harvard Crimson, May 5, 2009 available at http://www.thecrimson.com/article/2009/5/5/law-school-will-cutstaff-to/. 
of funding, and intensity of competition with other law schools in the specific market served by the law school also play important roles.

There is no single competitive formula or strategy generally applicable to all law schools. There are large-scale or macro-systemic factors that will have differential impacts on most law schools. But there are also context specific micro-systemic dynamics that depend on factors such as a particular school's national status or lack thereof, geographic location, applicant and employment markets served, public or private funding stresses, and number of competing institutions in the specific territorial or employment niche markets. ${ }^{116}$

One does not have to go further than the U.S. News \& World Report's annual ranking of American law schools to understand that the world of legal education is comprised of "haves" and "have-nots." These include internationally and nationally prominent institutions, regional and statedominant law schools, and a host of largely localized "wannabees" whose faculties espouse Harvard and Yale principles as justification for their mostly unread scholarship. The law faculties in the "wannabees" also tend to rely disproportionately on the models of teaching methods to which they were subjected in law school, the curricular structure, and course materials and content.

The reality is that U.S. law schools differ radically in numerous ways, some of which are real and others perceived. This includes, to a limited extent, differences in faculty quality, and in student quality, market access, resources, and the merit of their graduates. This does not denigrate law schools that are not named Harvard or Yale because, for example, the law school at which I spent most of my career has produced many graduates who have had stellar careers and made significant contributions as lawyers, judges, politicians and government workers, business leaders and even media icons such as Tim Russert who was one of my early clinical law students.

116. See Karen Sloan, Public Universities Begin Furloughing Employees-and Law Schools Are Not Exempt, NAT'L L.J., Feb. 12, 2009, available at http://www.law.com/jsp/nlj/PubArticleNLJ.jsp?id=1202428217990\&slreturn=1 \&hbxlogin=1 ("Public universities have begun furloughing employees in an effort to reduce costs, and law schools aren't exempt from the unpaid leave policies. For example, Arizona State University has implemented a university-wide furlough program that applies to the Sandra Day O'Connor College of Law. The move is expected to save the university about $\$ 24$ million at a time when the Arizona lawmakers are looking at significant cuts to state university funding. ... The president of the University of Missouri system, which maintains laws schools in Columbia and Kansas City, is considering furloughs and salary freezes. The University of Maine system, which includes the University of Maine School of Law, is in the process of finalizing a furlough program that would require certain workers to take two unpaid days prior to June 30. Faculty would be exempt from the furlough. The president of the University of North Carolina said last month that he expects to seek legislation to furlough university employees."). 
Excellence in the legal profession and life does not necessarily depend on one's LSAT score or the ability to compose written essays under the testing pressure of law school exams. These are the criteria that commonly provide the basis of hiring for new law professors. Success in law school has little or nothing to do with the qualities of passion, commitment, and high levels of human sensitivity and interactive skill that are needed to be a successful and effective lawyer.

Along with the competitive differences between law schools goes the issue of the cost of obtaining a law degree from a specific school. This involves not only the absolute dollars expended and debt incurred but the marketability of the school's degree in various employment contexts. The question of difference here is the extent to which the price of the degree is in a positive relationship with significant job opportunities and earnings levels.

The economic forces in play are coming from every direction and will prove irresistible. The writing is on the wall for law schools if they bother to read. Law schools are likely to find they share the need with other industries for a combination of actions that include downsizing of staff and reduced student enrollment, and development of alternative educational offerings other than the traditional law degree. Among the greatest sources of pressure will be budget cutting necessitated by mandated reduction demands from parent universities and state governments along with lower revenues from students. ${ }^{17}$

117. Daniel Mitchell (UCLA Management) has posted on the LERA Listserv a link to an article that highlights the proliferation of public sector employee furloughs. The article includes a handy state-by-state chart of both state employee furloughs and layoffs. The article, from Stateline.org, observes:

"Moving from furloughs of state employees to more permanent downsizing, states are girding for the deepest workforce cuts yet when they hammer out their fiscal 2011 budgets next year. . .

Since the recession began in December 2007, nearly all states have instituted hiring freezes, at least 75 percent have eliminated vacant positions and more than half have laid off and furloughed workers. In all, nearly 1 million state workers one in five-have been affected by the cutbacks, according to estimates compiled by Stateline.org.

After hiring freezes, furloughs are the preferred short-term option for most states, because they preserve morale and keep talented workers on the job for better days ahead. But experts say the benefits are illusory. The best employees still tend to look for other jobs."

Needless to say, states and their employees face challenging times ahead. Just from the perspective of law professors at state schools, the impact has already been dramatic. 
Schools such as Harvard and Yale will of course continue to exist but will be affected by issues of demand, the incredible costs of attending such institutions, and applicant quality. Nor can the competitive future of even some of the "elite" law schools be disconnected from the fact that the highest paying jobs are drying up for new graduates. This fact is known and increasingly filtering through the applicants' awareness. The problem for the most expensive law schools that are not Harvard, or the equivalent, is that there are few other options for earnings at the level required to pay off a $\$ 100,000$ to $\$ 150,000$ educational debt of the kind required to attend those law schools. This virtually ensures that a large law school such as Harvard will need to reduce enrollment, and smaller institutions such as Yale will dip lower in the credentials of its applicant pool.

Even this will have competitive implications as the traditional elites representing perhaps six law schools considered truly national (Harvard, Yale, Stanford, Chicago, Columbia, Michigan) along with others that are quasi-national or regionally dominant (Georgetown, NYU, Texas, Northwestern, Emory, USC, Iowa, Pennsylvania, Cornell) will siphon off applicants that had attended other well-regarded but lower ranked law schools, forcing these institutions to either reduce their size or adjust the quality of admitted students downward.

Outside the schools traditionally classed as the elite institutions, many law schools are entering an era in which their student bodies and faculties must shrink; where job security is reduced, life-tenure is questioned, and the level of acceptable productivity takes on a different meaning than showing up twice a week for classes and producing an occasional article every two or three years that is read only by a handful of academics who already agree with the author. There are, however, competitive options for many law schools to pursue. They include:

- Distance Learning Options aimed at cutting faculty costs, creating alternative learning methods. This offers the ability to create significant efficiencies by such means as a law school using one faculty member to teach several sections of the same course either through a live or recorded presentation. It also creates the ability to design teaching consortia between law schools in which faculty are shared. Law schools will be able to experiment with distance-based lectures for large scale information transfer classes followed with combinations of smaller seminars, tutorials and computer exercises.

Paul M. Secunda, The Proliferation of Public Sector Employee Furloughs and Layoffs, WORKPLACE PROF BLOG (Dec. 3, 2009), http://lawprofessors.typepad.com /laborprof_blog/2009/12/the-proliferation-of-public-sector-employee-furloughs-andlayoffs.html (last visited Jan. 11, 2011). 
- Creating an Attractive Market Niche (dispute resolution, trial, transactions, clinical law practice, health, medicine, insurance, small-scale practice concentrations, etc.) aimed at attracting applicants and serving the needs of the school's primary employers of law graduates. The niches can be ones of high-level generic lawyer skills and knowledge or more specialized areas of law that are customized to a particular market or need, whether local, regional or national.

- "Unbundling" Legal Education. There is no reason each law school should be all things to all students. Various ways exist in which American law schools could be "unbundled" and create a different and more flexible educational world. One way, for example, could be to allow law students to opt to attend one law school for basic analytical learning skills of the kind more or less imparted in the first year of law school as presently conceived, and then pick from a menu of schools that concentrate on offering a specialized upper-level curriculum, or pragmatic and intense skills and clinical programs that focus on improved preparation of students whose goals are to become effective lawyers capable of practicing at a high level of skill and professionalism.

- Downsizing Student Enrollment as reflecting the ability to maintain a student enrollment base of substantial quality while recognizing the reality of the saturated lawyer market in the regions most relevant to employment of its graduates.

- Downsizing Faculty as a cost-cutting move aimed at adjusting to create smaller law schools that more accurately reflect the demand for lawyers and the more restricted enrollments that should occur due to reduced need, a lower applicant pool either in quality or quantity, and reduction in financial support from parent universities or state funding sources.

- Using Shorter Term Contractual Faculty as a means of cutting costs and attracting a cadre of lawyers and judges who have a more focused and substantive understanding of law practice and critical social issues as played out in the system of law. This contrasts with the experience base of many law faculty who become increasingly attenuated in their connection with the world of law practice and who, in many instances, had very little experience prior to teaching to the degree that their knowledge and experience are obsolete and disconnected from the world for which they are purportedly preparing law students.

- Using More Adjunct Faculty as a cost-cutting move as well as a means of increased programmatic flexibility and adaptation. The distinction between adjunct and contractual faculty is that adjuncts are hired to teach a course periodically while contract faculty would 
generally be thought of as full-time faculty members during their period of service.

- Eliminating Esoteric Courses as means of focusing educational attention more on what lawyers actually do as opposed to what current law faculty want to teach. Students under the current system are being asked to carry the burden of funding faculty research that in many instances makes no contribution to their educational experience. Many of the courses attract very small numbers of students yet make up twenty-five to fifty percent of a faculty member's teaching load. This imposes significant resource costs on a law school that will become increasingly questionable as budgets continue to come under pressure.

- Increasing Faculty Workload as means of concentrating on the mission of teaching and reduction of law faculty scholarship. As indicated in the analysis, once the ABA moves away from measurement of faculty scholarly productivity in its accreditation process it will sound the death knell at some law schools of the publish or perish concept. The combination of the impending decline in tenure and the increase in contract and adjunct teachers, along with the rise of commercial law schools operated as businesses for profit will undermine the emphasis on scholarship among numerous law schools.

- Eliminating Tenure for all or all but a reduced central core of faculty provides a means for creating a lower cost and more flexible model for legal education that can be adjusted more easily to the pressures and fluctuations of the changing market. This will allow universities to adapt more efficiently and rapidly to the financial realities of declining enrollments and challenged budgets that will become commonplace in a significant number of law schools.

- Eliminating Publication Requirements based on the thesis that at least from an educational perspective the law schools are accredited to educate aspirants to law practice and that a significant proportion of academic legal research consists of a small group of faculty committed to a particular perspective speaking only to others who already share their views.

- Radically Altering Libraries because what is considered essential to a law school library has already undergone a significant shift to electronic information systems and away from expensive hard copies of law reports and other texts. Many law libraries are already ahead of their law schools in making adjustments to the technological advances.

- Creating Collaborative Consortia among law schools to reduce costs and offer economies of scale and innovative programs has the potential to enhance a law school's intellectual offerings through shared resources and access to highly knowledgeable specialists in a 
field. This can better distribute faculty expertise so that no institution has to be everything under the legal sun in faculty recruitment and retention.

- Improved Job Marketing in Target Areas. There is only a limited ability to alter the traditional markets, particularly in a time where the employment world has changed dramatically (and perhaps permanently) and the competition for jobs is far more intense. In an era of declining employment opportunities law schools need to focus on the areas of need in their primary and other important marketing sectors. This has obvious implications for faculty hiring, applicant appeal, resource allocation and the degree to which law schools seek to create productive interfaces with lawyers and businesses in their employment markets.

- Reducing Tuition. This can be done due to cuts in faculty and staff, as well as library budgets. But if applications drop and law schools reduce student bodies at the same time that states are deciding they cannot afford to subsidize law students due to lack of need and demand then reducing tuition can end up as a "death spiral." There are public schools (Michigan, Virginia and Michigan State) that charge the same level of tuition as private law schools. This may offer a partial strategy for a number of publicly funded law schools.

- Creating Tuition Forgiveness Programs for Public Service. This is a nod toward a whole additional subject, the way to use technology and the new market pressures to establish legal services for the middle class in a way that makes a decent living possible, essentially filling in the middle of the bimodal lawyer income distribution patterns and improving access to legal services.

- Accessing New Applicant Markets. This should be read in conjunction with the immediately following suggestion about the creation of new types of degree and non-degree programs. The idea involves multiple facets. One is the traditional move toward specialized Master of Law degrees that presumably allow a lawyer to gain both focused knowledge and a competitive edge relative to other lawyers who do not possess the added criteria. There is also the possibility of joint degree programs that include not only law study but business, accounting, or some other specialized area. In addition to seeking to attract applicants as a consequence of the degree programs, law schools can consider the possibility of some kind of alternative "non-practice" graduate degree in which people interested in understanding law but not intending to practice law can complete a course of study geared to that end. Another possibility is creating courses to be offered groups who are required or encouraged to take a continuing course of instruction. This might be elementary and secondary school teachers. 
- Creating New Types of Degree and Non-Degree Programs. This offers more hope than some other options because many people want to possess legal knowledge even if they don't want to practice law in the traditional sense. This could mean Corporate Law degrees, Health, Real Estate, Insurance or even Transactional or Alternative Dispute Resolution degrees. Many of these could be accomplished in a year to eighteen months at significantly lower expense and could open up entirely new markets for law schools.

- Adopting Some Variant of the British Educational Model in which undergraduate university students interested in law take a degree in five years that includes a combination of undergraduate study and law study. Graduates can obtain a first degree in law and then depending on their career interests pursue other degrees and training options. Rather than the American system where in order to be admitted to law school students must first complete four years of study and receive a degree and then take another very expensive three or four year course of study for a Juris Doctor degree, the British system offers a degree in five rather than seven or eight years. Nor, having taught in each system, can I say the American system is superior.

\section{CONCLUSION}

The points raised in this Essay describe concerns about the competitive climate that faces American law schools. From a strategic perspective oriented to business, economic, and financial conditions, the most critical approach is to be able to perceive what is happening as a loosely integrated process that generates pressures, competitive alternatives and significant consequences for a significant number of law schools. This is what I have attempted to capture.

From a strategic standpoint, law schools have relatively little ability to control or even influence some of the most important driving forces that are creating this competitive environment. Distance learning and a rapid increase in corporate-owned law schools for profit will produce alternative competitive models for legal education with which many intermediate and lower ranked law schools will find it difficult to compete. In my experience, few law school deans and almost no traditional law school faculty have the understanding or the political will that will be required to cope with the pressures and strategic reality.

Financial resources are of course critical to schools' survival and health. The problem, however, is that states face growing budget deficits at a time when demands for critical social services are increasing. Public law schools in such areas can expect to see substantial belt-tightening that will require hard decisions that will not make law faculty members and adminis- 
trators at those law schools very happy. Intermediate and lower ranked law schools in areas under intense budget pressures, shrinking economies and a saturation of lawyers could easily see the bottom fall out of their applicant pools with startling rapidity.

Another element of this problem is that stagnant economies and saturated employment markets offer situations where, as noted above, law schools can implement actions that make some difference on the competitive margins, but many graduates and schools will still be left out in the cold in terms of jobs, applicants and plummeting student satisfaction.

We have entered a period in which many of the assumptions that have been applied to legal education no longer hold true. It will be a time when the classic rhetoric used by law school deans and faculty to justify the expensive and bloated model of legal education will lose their power to protect turf. It is an era in which the working conditions of law faculty will change dramatically in ways that current faculty would consider highly negative.

Finally, it is a time when all the traditional and still existing rules and assumptions made about the form of legal education and the structure and methods of law schools will be subject to examination. This is as it should be. Having spent a significant part of my life not only as a law professor but as a lawyer interacting with judges and lawyers on cases and other transactional issues, I can say without hesitation that while there are many good lawyers who provide professional services at high levels of quality, there are also many bad lawyers whose clients are betrayed by incompetence, greed, case "churning" and overbilling, and the like. Even with the good lawyers, there is no obvious connection or empirical validation of the results being achieved due to what they were exposed to in law school as opposed to talent, commitment and a sense of duty to the client. If law schools point to excellent lawyers as justification for their educational model, they should also be required to explain why so many lawyers disserve their clients and provide mediocre to poor legal representation.

When the inevitable questions are finally asked about the value-added qualities produced by the traditional model of American legal education I fear that there will be few valid answers provided from within the academy. The pressures will not come mainly from within law schools themselves or even from friendly accrediting agents in the ABA's Section on Legal Education and Admission to the Bar that tends to be dominated by law school faculty and administrators, but from outside and largely uncontrollable sources such as faceless economic trends, shrinking state budgets and increasingly hostile university administrators. 